This work is licensed under a Creative Commons Attribution 3.0 License.

\author{
Research article \\ urn:1sid:zoobank.org:pub:FE328725-7017-417D-B140-71D830B89316
}

\title{
The species of Moloha Barnard, 1946, from the western Indian Ocean, with the description of a new species from India (Crustacea: Brachyura: Homolidae)
}

\author{
Peter K.L. NG ${ }^{1, *}$ \& Appukuttannair Biju KUMAR ${ }^{2}$ \\ ${ }^{1}$ Lee Kong Chian Natural History Museum, Faculty of Science, National University of Singapore, \\ 2 Conservatory Drive, Singapore 117377, Republic of Singapore. \\ ${ }^{2}$ Department of Aquatic Biology \& Fisheries, University of Kerala, Kariavattom, \\ Thiruvananthapuram - 695581, Kerala, India. Email:abiju@rediffmail.com \\ *Corresponding author: peterng@nus.edu.sg \\ ${ }^{1}$ urn:1sid:zoobank.org:author:8ACB5B5C-7DC3-43A7-82E4-420AD0FF7377 \\ ${ }^{2}$ urn:lsid:zoobank.org:author:B07B1EE1-AD4E-4FEC-A968-90A4A831ACA1
}

\begin{abstract}
The taxonomy of the deep-water homolid crabs Moloha grandperrini Guinot \& Richer de Forges, 1995 and M. alisae Guinot \& Richer de Forges, 1995 is re-examined, and the types redescribed and figured. Moloha alisae is reported from South Africa for the first time. A new species with an inflated carapace, M. tumida sp. nov., is also described from southern India and compared with its closest congeners.
\end{abstract}

Keywords. Crustacea, Homolidae, Moloha, India, taxonomy.

Ng P.K.L. \& Kumar A.B. 2015. The species of Moloha Barnard, 1946, from the western Indian Ocean, with the description of a new species from India (Crustacea: Brachyura: Homolidae). European Journal of Taxonomy 166: 1-25. http://dx.doi.org/10.5852/ejt.2015.166

\section{Introduction}

The Indo-Pacific homolid genus Moloha Barnard, 1946 currently contains six species: M. acutispina (Sakai, 1961), M. alcocki (Stebbing, 1920), M. alisae Guinot \& Richer de Forges, 1995, M. faxoni (Schmitt, 1921), M. grandperrini Guinot \& Richer de Forges, 1995 and M. majora (Kubo, 1936) (see Guinot \& Richer de Forges 1995; Richer de Forges \& Ng 2007, 2008). Guinot \& Richer de Forges (1995) were unsure about the identity of Paromola alcocki fanghni Serène \& Lohavanijaya, 1973, and whether it belonged to Moloha; the subspecies was described from a small male from the South China Sea. Ng (2015) recently showed that it was a species of Paromola Wood-Mason in Wood-Mason \& Alcock, 1891 s. str.

In their revision of the Homolidae, Guinot \& Richer de Forges (1995) recognised three species of Moloha from the western Indian Ocean: M. alcocki (Stebbing, 1920), M. alisae Guinot \& Richer de Forges, 1995 and M. grandperrini Guinot \& Richer de Forges, 1995. Contrary to earlier confusion about the identity of M. alcocki (e.g., Gordon 1950; Serène \& Lohavanijaya 1973; Kensley 1980), Guinot \& 
Richer de Forges (1995: 380) showed that M. alcocki s. str. is actually a very distinct species, markedly different from all congeners in its prominently laterally flattened ambulatory meri. Moloha alisae and M. grandperrini, while distinct from M. alcocki s. str. (notably with subcylindrical legs), were both only described from single specimens.

The authors recently obtained an interesting homolid crab from deep-sea trawlers operating off the coast of Kerala in southwestern India. While superficially similar to Moloha grandperrini, it differs in a number of carapace and pereopod characters. This prompted us to re-examine the types of M. alisae and $M$. grandperrini. The study of these as well as recent homolid specimens from South Africa led us to the conclusion that the Indian specimen is actually a new species of Moloha.

\section{Material and methods}

The measurements for the carapace are as follow:

tcl $=$ total carapace length, including spines

$\mathrm{tcw}=$ total carapace width, including spines

$\mathrm{cl}=$ carapace length, measured at bases of spines

$\mathrm{cW}=$ carapace width, measured at bases of spines

The terminology used follows that by Guinot \& Richer de Forges (1995). The abbreviations P1-P5 are used for the first to fifth ambulatory legs, including the chelipeds; G1 and G2 for the male first and second gonopods, respectively. The counts for the spines on the margins and surfaces of P1-P5 include tubercles and distinct sharp granules, which are sometimes not easy to distinguish because they vary in sizes and degree. As such, we use the term spines for all these structures. For the dorsal row, it includes the large distal spine. The spines along the ventral (flexor) margin of the merus actually form approximately two rows proximally but merge towards the distal end. As such, the number of spines on the ventral margin is a total count. Specimens examined are deposited in the Department of Aquatic Biology \& Fisheries, University of Kerala (DABFUK), India; The Natural History Museum (NHM), London; Muséum national d'Histoire naturelle (MNHN), Paris; and the Zoological Reference Collection (ZRC) of the Lee Kong Chian Natural History Museum (formerly the Raffles Museum of Biodiversity Research), National University of Singapore.

\section{Results}

Infraorder Brachyura Latreille, 1802

Superfamily Homoloidea H. Milne Edwards, 1837

Family Homolidae H. Milne Edwards, 1837

Genus Moloha Barnard, 1946

\section{Type species}

Latreillopsis alcocki Stebbing, 1920, by original designation.

\section{Remarks}

Most workers (e.g., Gordon 1950; Serène \& Lohavanijaya 1973; Guinot \& Richer de Forges 1995; Ahyong et al. 2009; Garassino 2009) cite the author of Moloha as "Barnard, 1947". This is incorrect. Evenhuis (2003) dated the volume of the journal concerned as 29 April 1946. The genus should therefore be cited as Moloha Barnard, 1946. In that paper, Barnard also described two new genera (Eudromidia and Speodromia) and 10 new species (Dromidia aegibotus, D. dissothrix, Dromidiopsis cornuta (at present Dromidia), Cryptodromidiopsis lepidota (at present Dromidia), Hexapus stebbingi (at present Tritoplax), 
NG P.K.L. \& KUMAR A.B., Species of Moloha from the western Indian Ocean

Rhynchoplax bovis (at present Neorhynchoplax), Heteronucia angulata, Dehaanius undulatus (at present Acanthonyx), Portumnus mcleayi (at present Xaiva) and Lybia plumosa) from South Africa. The author and date for all these taxa should be "Barnard, 1946" as well.

Moloha grandperrini Guinot \& Richer de Forges, 1995

Figs $1 \mathrm{~A}, 3 \mathrm{~A}, 4 \mathrm{~A}, 5 \mathrm{~A}, 6,10,14 \mathrm{~A}, 15 \mathrm{~A}-\mathrm{C}$

Moloha grandperrini Guinot \& Richer de Forges, 1995: 391, fig. 33 a-b, e-f.

Paromola alcocki - Gordon 1950: 222, pl. 1, fig. A (not Latreillopsis alcocki Stebbing, 1920).

Moloha grandperrini - Ng et al. 2008: 41 (list).

\section{Diagnosis}

Carapace with pseudorostral and supraocular spines long, subequal; supraocular spine with distinct submedian accessory spine; gastric region with small but distinct sharp granules in addition to 3 major spines; branchial regions convex; subhepatic region swollen, with 2 large dorsal and 2 small ventral spines; protogastric region with 2 major spines; basal antennal spine triangular, relatively broad; P2-P4 long, slender, subcylindrical, merus with 6 or 7 spines on dorsal margin, outer surface with 3-10 small spines, ventral margin with 15-21 spines; P5 with 1 or 2 spines on dorsal margin, 4 small spines on outer surface, 4 or 5 spines on ventral margin, subchelate structure stout, propodus with 3 large basal spines, rest of margin with distinct, closely arranged spines of similar size. G1 stout, short, groove on ventral surface median, dorso-median surface concave, distal part rounded, opening relatively smaller, flap-like, not auriculiform, directed towards median part of sternum.

\section{Material examined}

MALDIVES: Holotype, ô (tcl $53.0 \mathrm{~mm}$, cl $46.5 \mathrm{~mm}$, tcw $46.4 \mathrm{~mm}$, cw $39.0 \mathrm{~mm}$ ), station 157, area zoo 2015-374T, 229 m, Maldives, coll. John Murray Expedition, 5 Apr. 1934 (NHM 1948.9.7.27).

\section{Distribution}

The species was described from the Maldives and has not been reported elsewhere.

\section{Remarks}

See Discussion section for comparisons.

Moloha alisae Guinot \& Richer de Forges, 1995

Figs 2, 3C-D, 4B, 5C-D, 7-8, 11-12, 14C-D, 16, 17A

Moloha alisae Guinot \& Richer de Forges, 1995: 389, figs 29e-f, 51i-k.

Moloha alisae - Ng et al. 2008: 41 (list).

\section{Diagnosis}

Carapace with pseudorostral and supraocular spines long, subequal; supraocular spine with distinct submedian accessory spine; gastric region with 3 major spines, surface between them smooth, unarmed; branchial regions gently convex; subhepatic region swollen, with 2 large dorsal and 2-4 small ventral spines; protogastric region with 2 major spines; basal antennal spine triangular, relatively broad; P2-P4 very long, slender, subcylindrical, merus with 6-10 spines on dorsal margin, outer surface with 1-9 small spines, ventral margin with 8-26 spines; P5 with 1-3 spines on dorsal margin, 2-4 small spines on outer surface, $2-5$ spines on ventral margin, subchelate structure relatively longer, spines on flexor margin are spaced further apart, relatively smaller distally. G1 stout, short, groove on ventral surface median, dorso-median surface concave, distal part less rounded, opening relatively smaller, flap-like, not auriculiform, directed towards median part of sternum. 


\section{Material examined}

SEYCHELLES: Holotype, ô (tcl $40.6 \mathrm{~mm}$, cl $36.1 \mathrm{~mm}$, tcw $33.9 \mathrm{~mm}$, cw $29.7 \mathrm{~mm}$ ), 16.4⒊ $34.7^{\prime} \mathrm{S}$, 56 25.6' E, stn 3, 390-410 m, coll. CEPROS Expedition, A. Intès, 22 Oct. 1987 (MNHN-IU-2008-11077, ex MNHN-B 20289).

SOUTH AFRICA: 2 đึ (tcl $80.3 \mathrm{~mm}, \mathrm{cl} 67.7 \mathrm{~mm}$, tcw $64.6 \mathrm{~mm}$, cw $56.2 \mathrm{~mm}$; tcl $78.9 \mathrm{~mm}, \mathrm{cl} 67.5 \mathrm{~mm}$, tcw [spines broken], cw $56.5 \mathrm{~mm}$ ), Eastern Cape, Port Elizabeth, Bay World, off Kenton, coll. S. Warren, Jun. 2004 (ZRC 2008.1250).

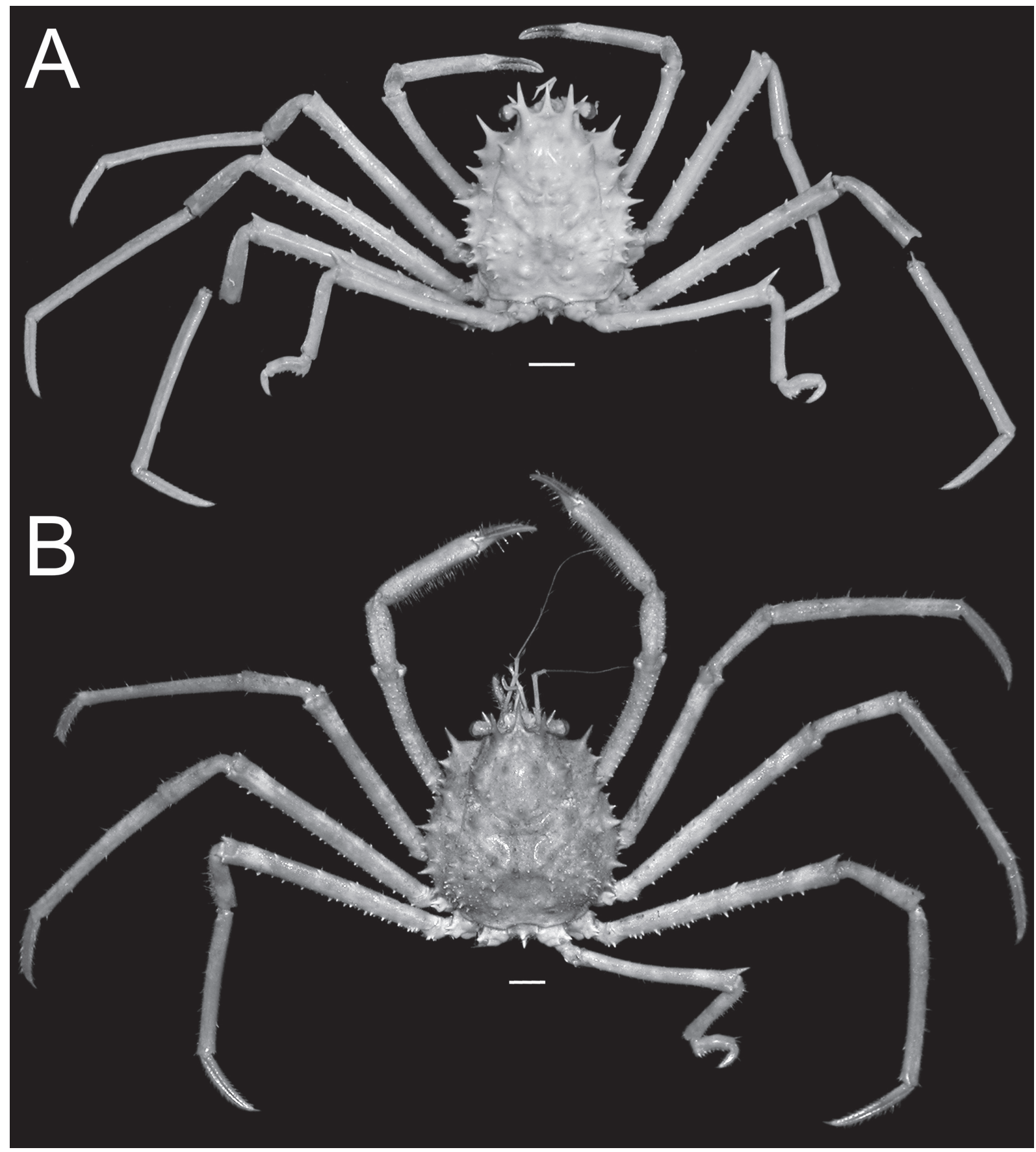

Fig. 1. Overall habitus. A. Moloha grandperrini Guinot \& Richer de Forges, 1995. Holotype, $\widehat{\partial}$ (cl

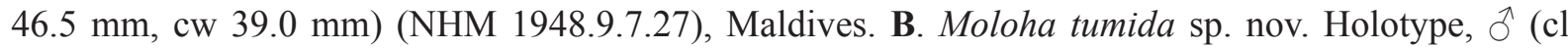
$55.7 \mathrm{~mm}$, cw $50.6 \mathrm{~mm}$ ) (DABFUK), Kerala, India. Scale bars $=10 \mathrm{~mm}$. 
NG P.K.L. \& KUMAR A.B., Species of Moloha from the western Indian Ocean

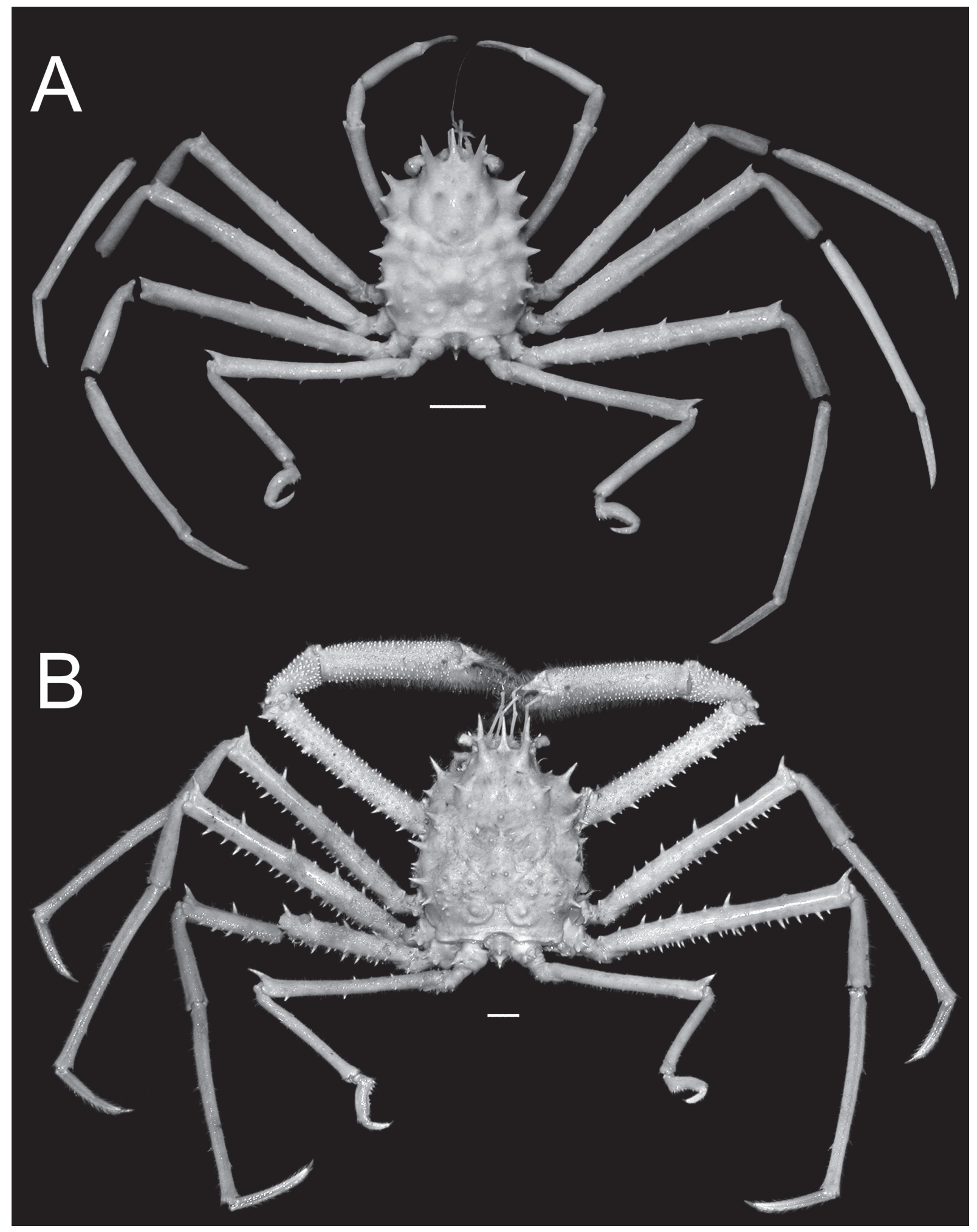

Fig. 2. Overall habitus. Moloha alisae Guinot \& Richer de Forges, 1995. A. Holotype, $\widehat{\partial}$ (cl $36.1 \mathrm{~mm}$, cw $29.7 \mathrm{~mm}$ ) (MNHN-IU-2008-11077), Seychelles. B. ô (cl $67.5 \mathrm{~mm}$, cw $56.5 \mathrm{~mm}$ ) (ZRC 2008.1250b), South Africa. Scale bars $=10 \mathrm{~mm}$. 


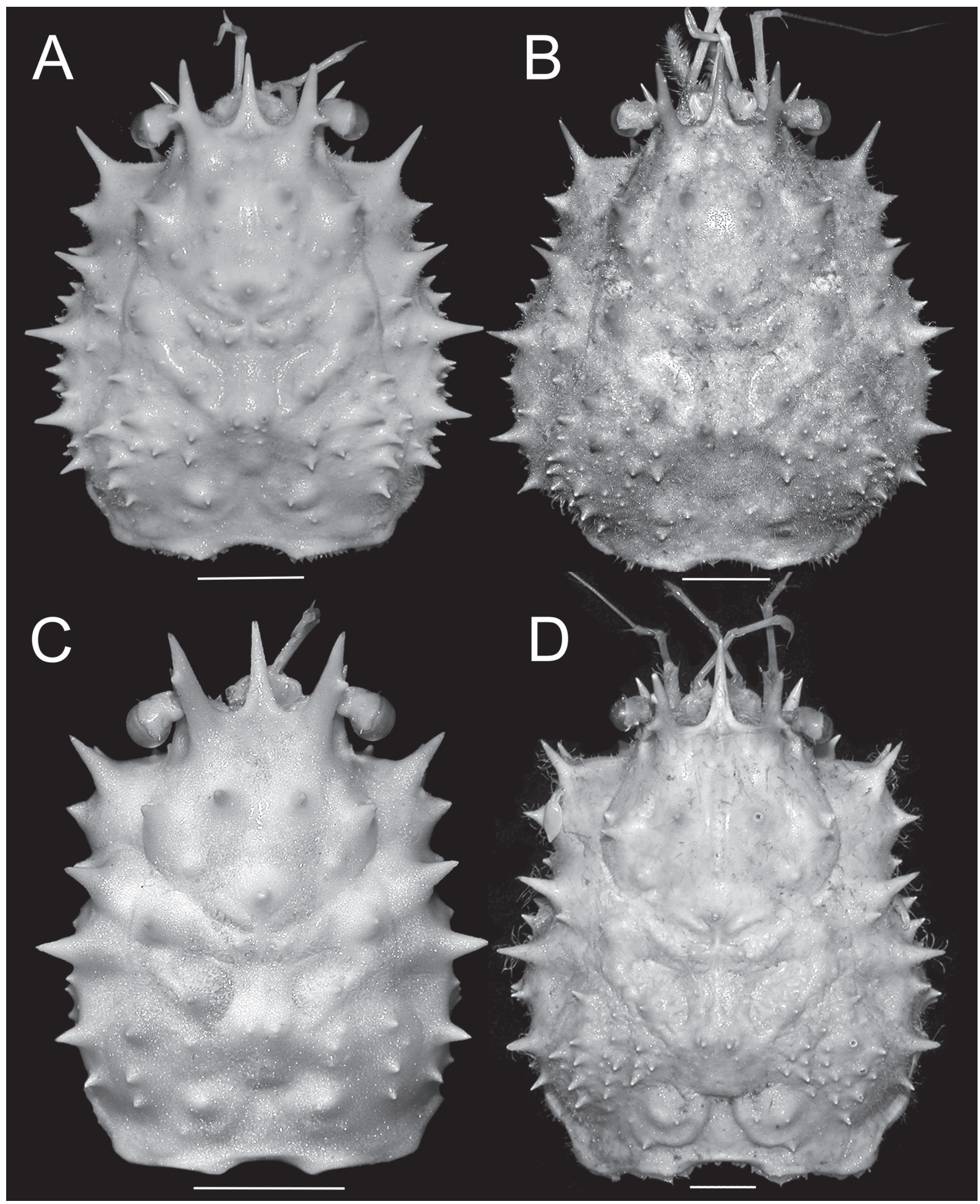

Fig. 3. Dorsal view of carapace. A. Moloha grandperrini Guinot \& Richer de Forges, 1995. Holotype, § (cl $46.5 \mathrm{~mm}$, cw $39.0 \mathrm{~mm}$ ) (NHM 1948.9.7.27), Maldives. B. Moloha tumida sp. nov. Holotype, § (cl $55.7 \mathrm{~mm}$, cw $50.6 \mathrm{~mm}$ ) (DABFUK), Kerala, India. C. Moloha alisae Guinot \& Richer de Forges, 1995. Holotype, ô (cl $36.1 \mathrm{~mm}$, cw $29.7 \mathrm{~mm}$ ) (MNHN-IU-2008-11077), Seychelles. D. Moloha alisae Guinot \& Richer de Forges, 1995. ô (cl 67.7 mm, cw $56.2 \mathrm{~mm}$ ) (ZRC 2008.1250a), South Africa. Scale bars $=10 \mathrm{~mm}$. 
NG P.K.L. \& KUMAR A.B., Species of Moloha from the western Indian Ocean

\section{Colour}

In life, the carapace, chelipeds and ambulatory legs are orange with patches of white (Fig. 17A).

\section{Distribution}

The species was described from the Seychelles; the present record from South Africa is new.

\section{Remarks}

The holotype male of M. alisae is small (MNHN-IU-2008-11077; cl $36.1 \mathrm{~mm}$, cw $29.7 \mathrm{~mm}$ ) and, although the G1 and G2 are present, it is clearly still a juvenile. The male pleon is not domed (Fig. $7 \mathrm{E}$ ) and the gonopods are still not strongly chitinised, being relatively soft (Figs 7C, 16A-C). We have referred the two large specimens from South Africa (ZRC 2008.1250) to this species because it matches the holotype in most key aspects: the carapace shape is distinctly rectangular, the surfaces between the major spines on the gastric region are smooth and unarmed, the cardio-intestinal groove is deep, and P5 is long, reaching to the base of the pseudorostral spines when folded anteriorly. Another shared character is the proportionately longer P5 propodus of the subchelate structure, which has the teeth on the distal half of the flexor margin more widely spaced (Figs 11F, K, 12F, H-J). In M. grandperrini and M. tumida sp. nov., the P5 propodus is relatively shorter and the flexor margin has more closely arranged teeth of similar sizes (Figs 10F, 13I).

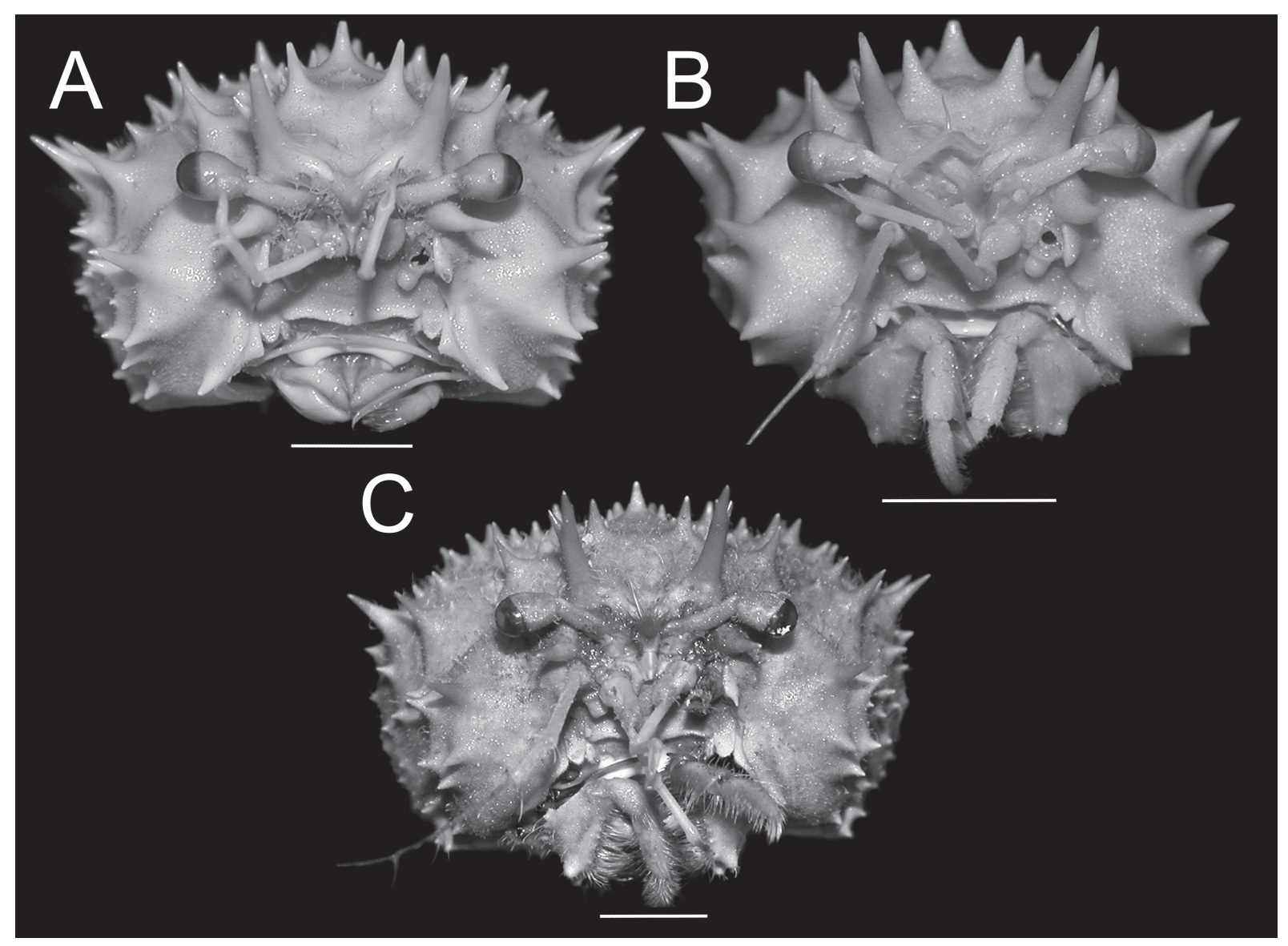

Fig. 4. Frontal view of cephalothorax. A. Moloha grandperrini Guinot \& Richer de Forges, 1995. Holotype, đ (cl $46.5 \mathrm{~mm}$, cw $39.0 \mathrm{~mm}$ ) (NHM 1948.9.7.27), Maldives. B. Moloha alisae Guinot \& Richer de Forges, 1995. Holotype, đ̊ (cl $36.1 \mathrm{~mm}$, cw $29.7 \mathrm{~mm}$ ) (MNHN-IU-2008-11077), Seychelles. C. Moloha tumida sp. nov. Holotype, $\widehat{\jmath}$ (cl $55.7 \mathrm{~mm}$, cw $50.6 \mathrm{~mm}$ ) (DABFUK), Kerala, India. Scale bars $=10 \mathrm{~mm}$. 
However, there are a number of differences which we believe are size-related and not significant at the species level. The branchial surfaces of the two large South African specimens are covered with relatively more spinules between the major spines (Figs 2B, 3D, 14D) compared to those on the holotype male (Figs 2A, 3C, 14C). In addition, the P5s of the two largest South African males are still relatively shorter than those of the holotype male from the Seychelles, reaching only to the base of the pseudorostral spines (Fig. 14D) and not to the median part of the spines (Fig. 14C). The armature of P2-P5 is substantially stronger in the two South African males (Fig. 12B-D) compared to that on the holotype male (Fig. 11B-D, G-I; Table 1). There is also a slight difference in the form of the distal part of the G1. In the large South African males, the distal part is more bulbous, with the opening relatively large (Fig. 16D-E), while in the smaller Seychelles male, it is less swollen, with the opening smaller and more folded (Fig. 16A-B). The chelipeds of the two South African males are typical of many large mature homolids, being elongated, stout, the surfaces granular and covered with dense setae (Fig. 8C, E). Those of the holotype male from the Seychelles (Fig. 7E-F) clearly belong to a juvenile. As such, it is best to refer the two large South African specimens to M. alisae for the time being, at least until more material becomes available from the area, especially belonging to intermediate size-classes.

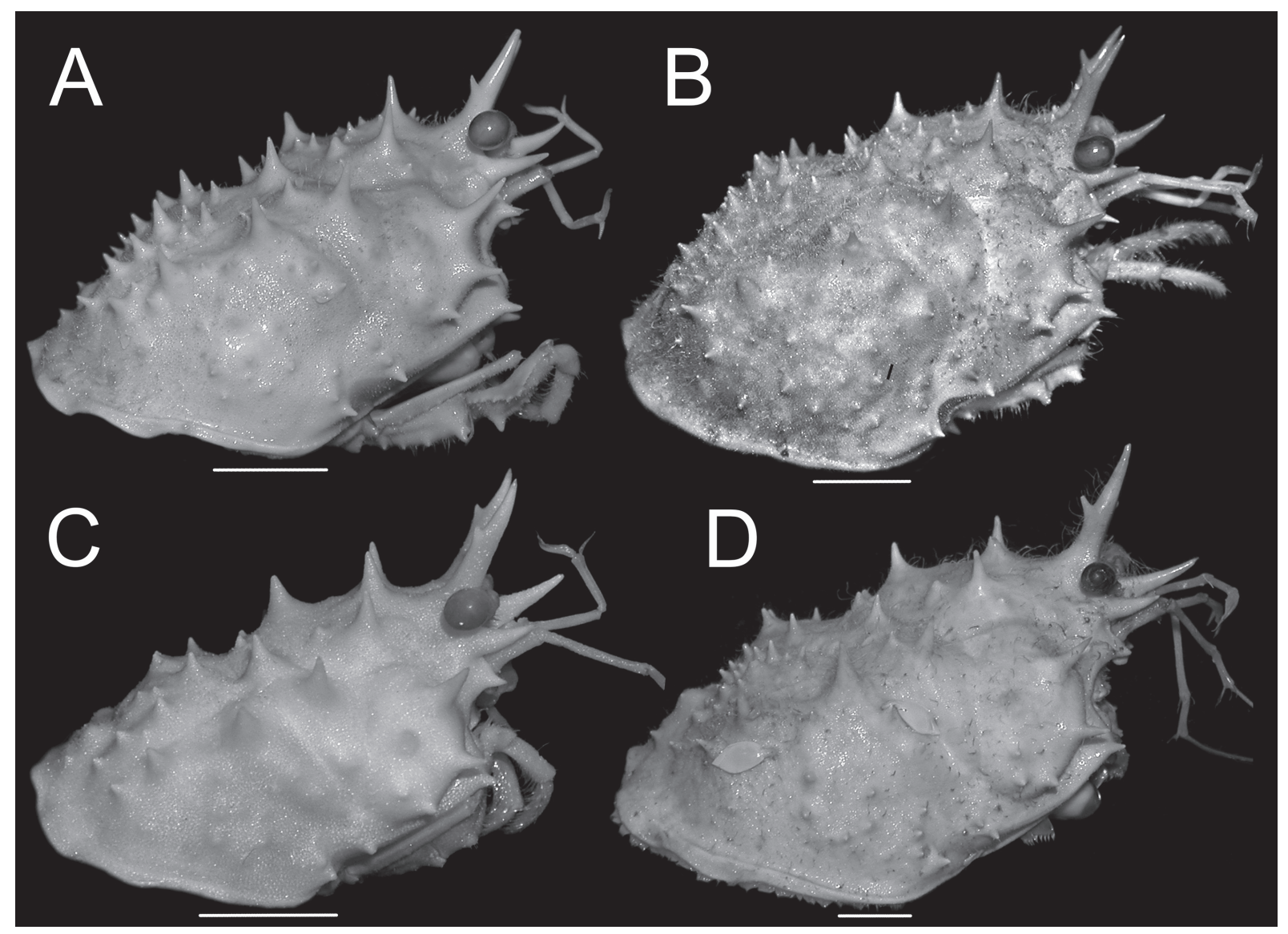

Fig. 5. Lateral view of cephalothorax. A. Moloha grandperrini Guinot \& Richer de Forges, 1995. Holotype, $\widehat{\jmath}$ (cl $46.5 \mathrm{~mm}$, cw $39.0 \mathrm{~mm}$ ) (NHM 1948.9.7.27), Maldives. B. Moloha tumida sp. nov. Holotype, ô (cl $55.7 \mathrm{~mm}$, cw $50.6 \mathrm{~mm}$ ) (DABFUK), Kerala, India. C. Moloha alisae Guinot \& Richer de Forges, 1995. Holotype, ô (cl $36.1 \mathrm{~mm}$, cw $29.7 \mathrm{~mm}$ ) (MNHN-IU-2008-11077), Seychelles. D. Moloha alisae Guinot \& Richer de Forges, 1995. đo (cl 67.7 mm, cw $56.2 \mathrm{~mm}$ ) (ZRC 2008.1250a), South Africa. Scale bars $=10 \mathrm{~mm}$. 
NG P.K.L. \& KUMAR A.B., Species of Moloha from the western Indian Ocean

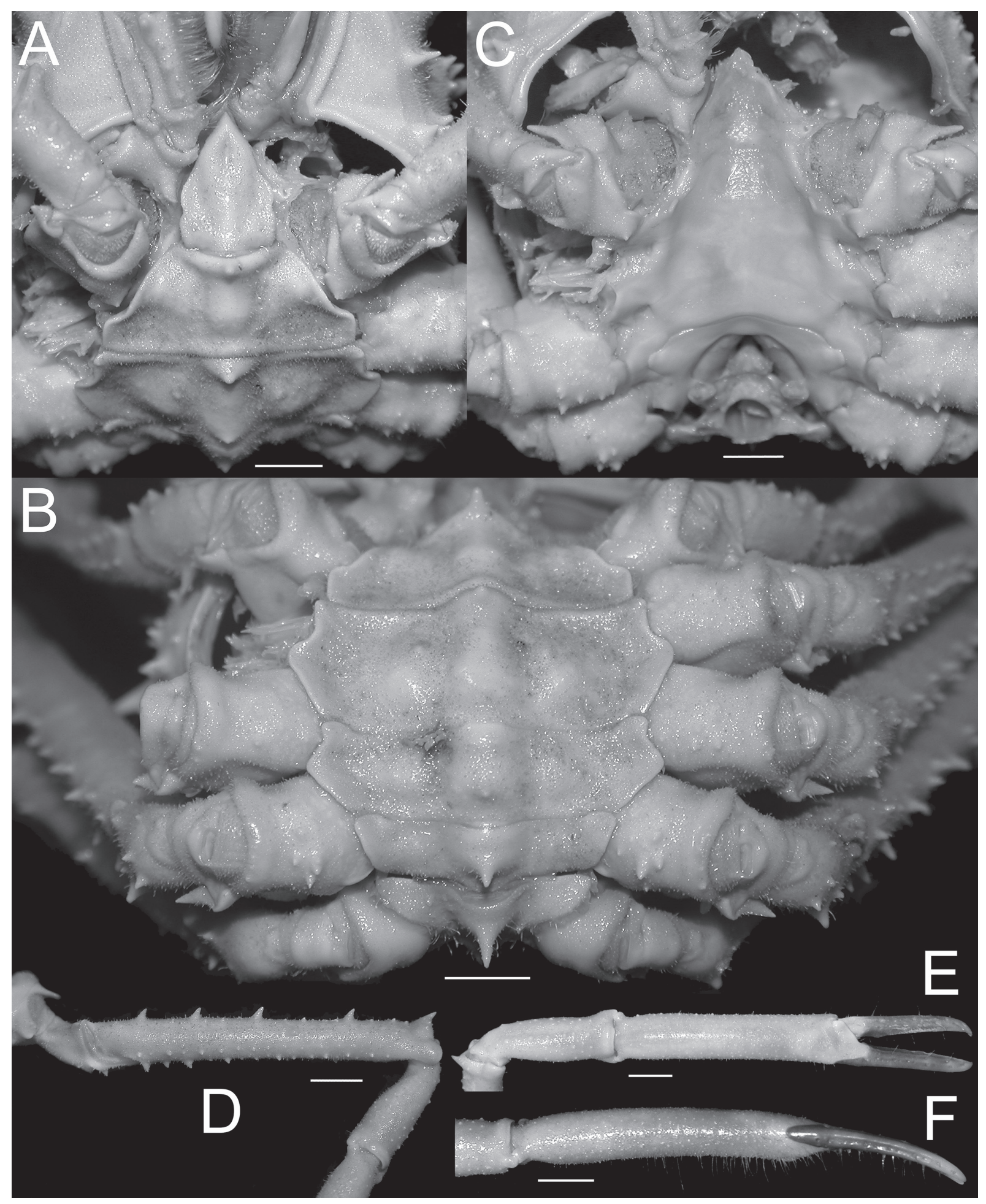

Fig. 6. Moloha grandperrini Guinot \& Richer de Forges, 1995. Holotype, $\widehat{\curlywedge}$ (cl $46.5 \mathrm{~mm}$, cw $39.0 \mathrm{~mm}$ ) (NHM 1948.9.7.27), Maldives. A. Telson and pleonal somites 5 and 6. B. Pleonal somites 2-6. C. Sternopleonal cavity. D. Merus and carpus of right cheliped. E. Outer view of right chela. F. Ventromarginal view of right chela. Scale bars $=5 \mathrm{~mm}$. 
The presence of M. alisae in South Africa means that there are now two species of Moloha in its waters, the other being the type species, M. alcocki s. str..

For additional comparisons, see the Discussion section.

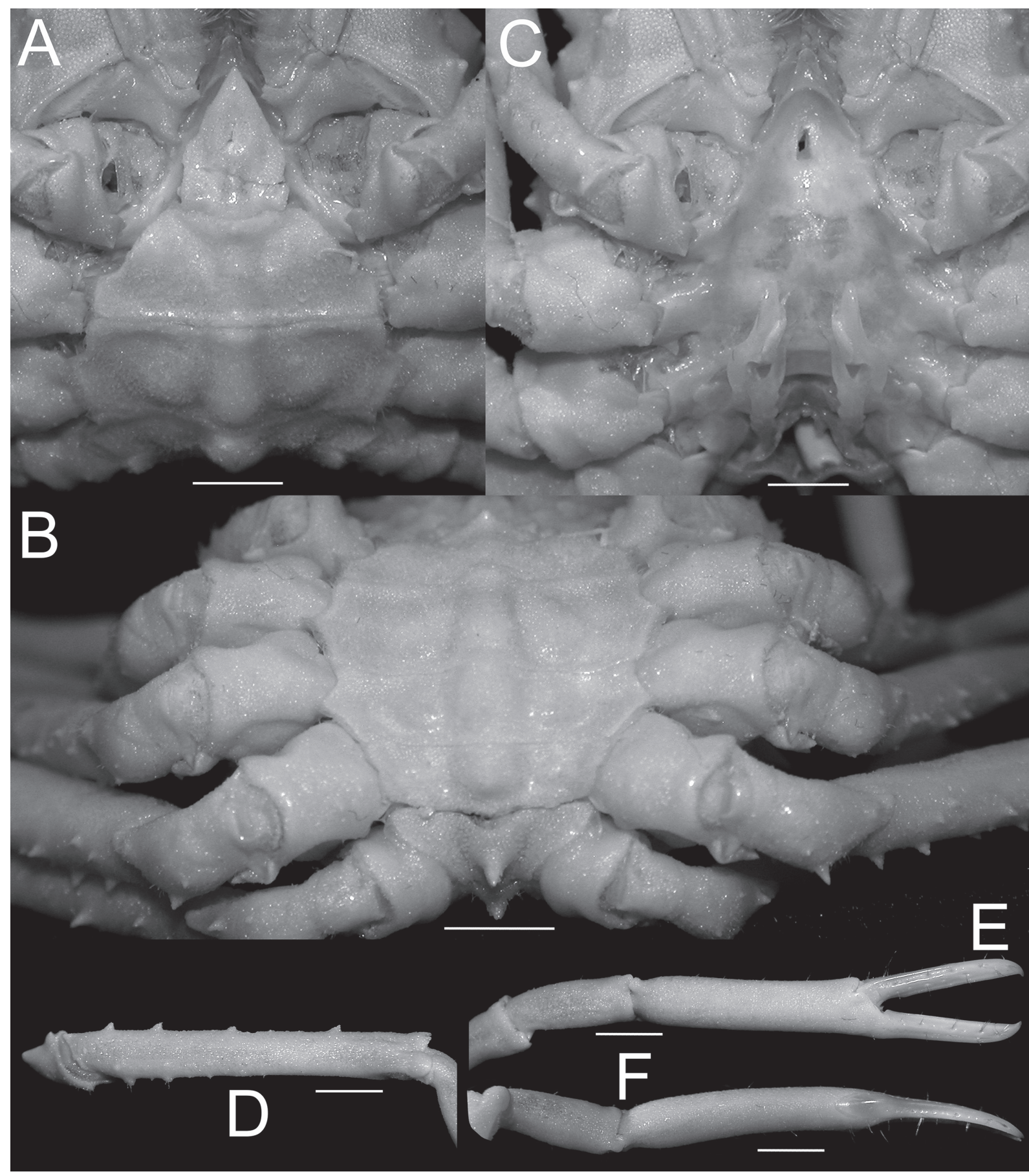

Fig. 7. Moloha alisae Guinot \& Richer de Forges, 1995. Holotype, ô (cl $36.1 \mathrm{~mm}$, cw $29.7 \mathrm{~mm}$ ) (MNHN-IU-2008-11077), Seychelles. A. Telson and pleonal somites 5 and 6. B. Pleonal somites 2-6. C. Sternopleonal cavity. D. Merus and carpus of right cheliped. E. Outer view of right chela. F. Ventromarginal view of right chela. Scale bars $=5 \mathrm{~mm}$. 
NG P.K.L. \& KUMAR A.B., Species of Moloha from the western Indian Ocean

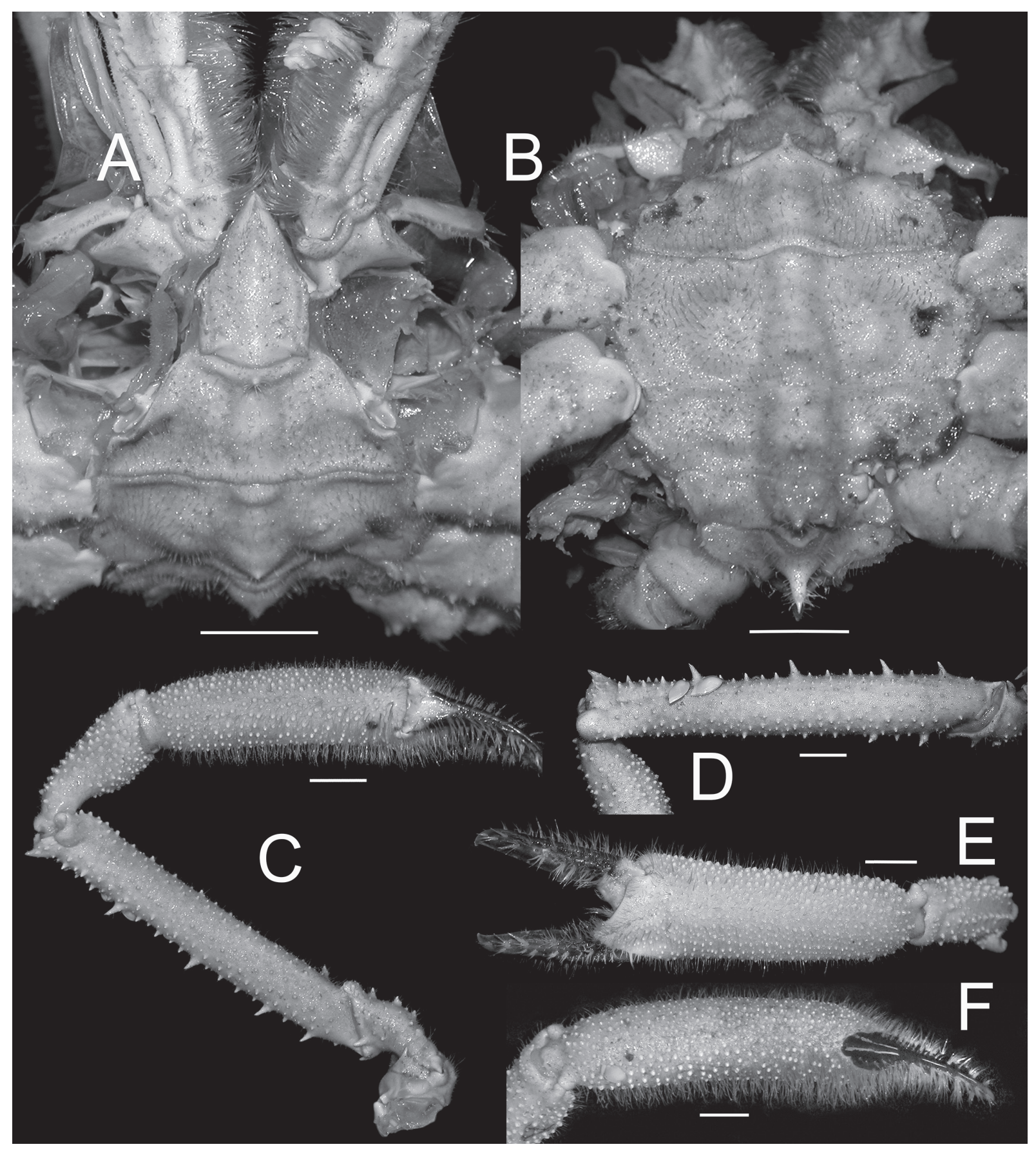

Fig. 8. Moloha alisae Guinot \& Richer de Forges, 1995. A-B. ठ̊ (cl $67.7 \mathrm{~mm}$, cw $56.2 \mathrm{~mm}$ ) (ZRC 2008.1250a), South Africa. C-F. ठ̊ (cl $67.5 \mathrm{~mm}$, cw $56.5 \mathrm{~mm}$ ) (ZRC 2008.1250b), South Africa. A. Telson and pleonal somites 5 and 6. B. Pleonal somites 2-6. C. Left cheliped. D. Lateral view of merus and carpus of left cheliped. E. Outer view of right chela. F. Ventro-marginal view of right chela. Scale bars $=10 \mathrm{~mm}$. 


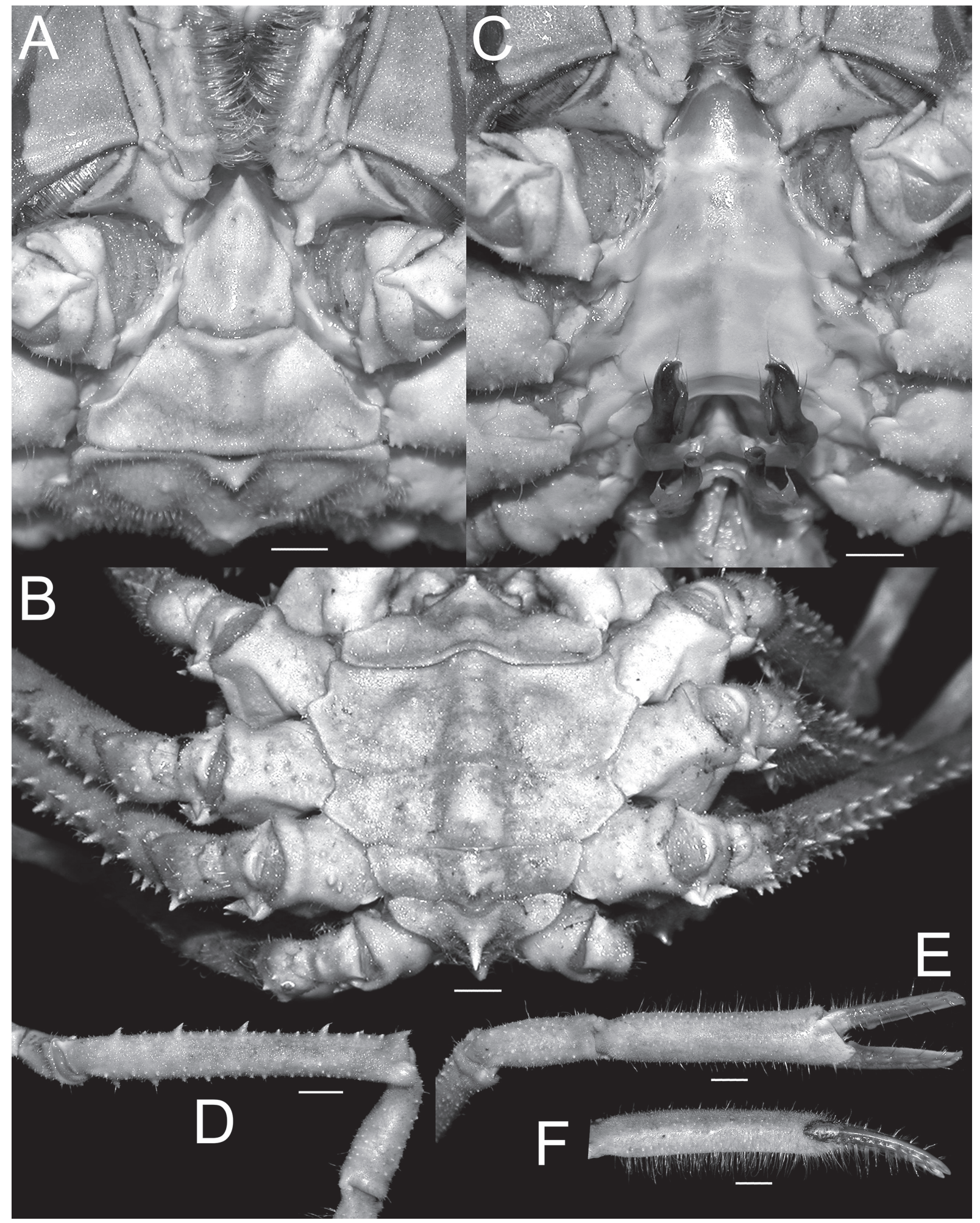

Fig. 9. Moloha tumida sp. nov. Holotype, ô (cl $55.7 \mathrm{~mm}$, cw $50.6 \mathrm{~mm}$ ) (DABFUK), Kerala, India. A. Telson and pleonal somites 5 and 6. B. Pleonal somites 2-6. C. Sternopleonal cavity. D. Merus and carpus of right cheliped. E. Outer view of right chela. F. Ventro-marginal view of right chela. Scale bars $=5 \mathrm{~mm}$. 
NG P.K.L. \& KUMAR A.B., Species of Moloha from the western Indian Ocean

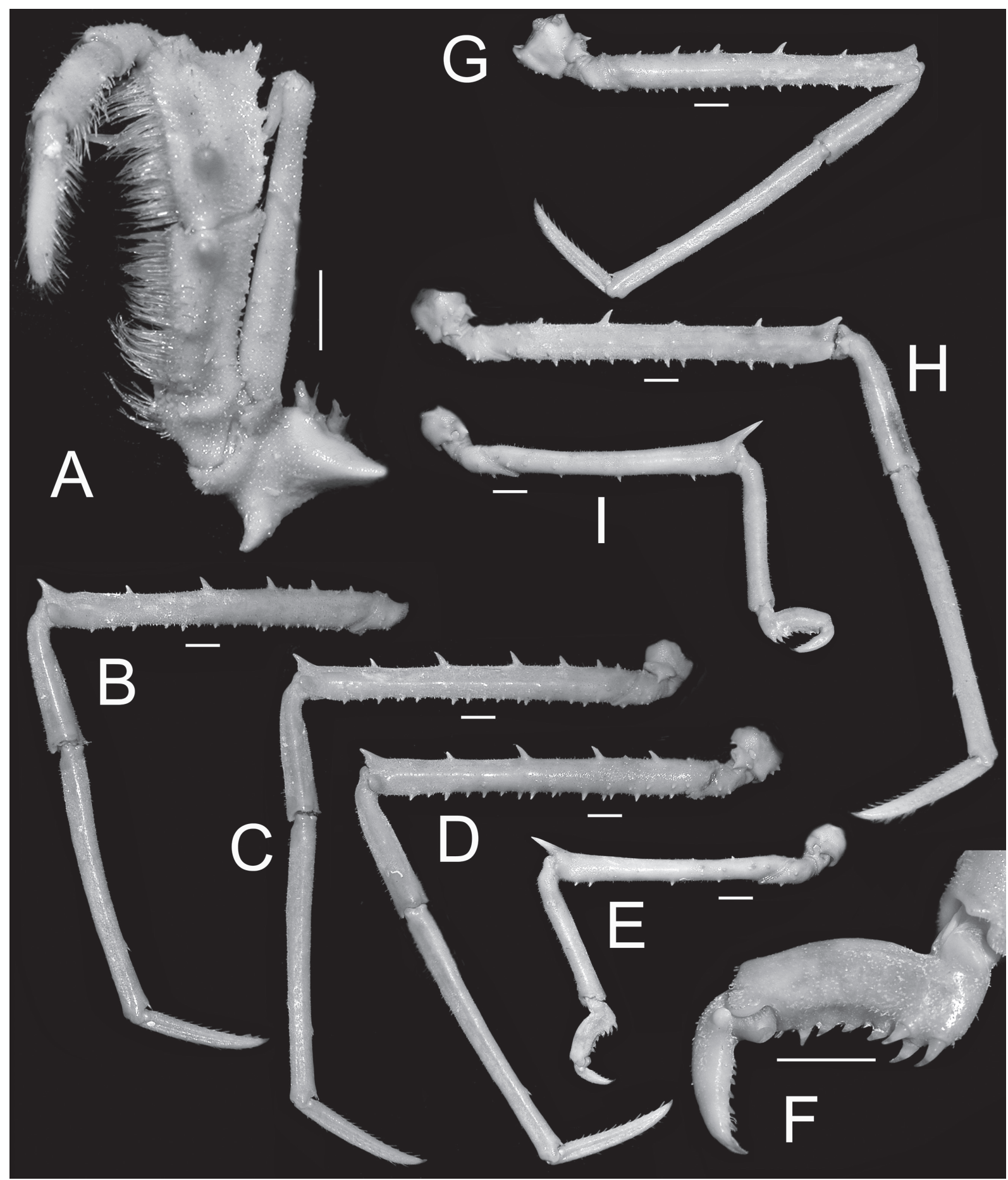

Fig. 10. Moloha grandperrini Guinot \& Richer de Forges, 1995. Holotype, $\widehat{~}$ (cl 46.5 mm, cw $39.0 \mathrm{~mm})$ (NHM 1948.9.7.27), Maldives. A. Left third maxilliped. B-E. Left P2-P5, respectively. F. Left P5 subchelate dactylus and propodus. G. Right P2. H-I. Right P4 and P5, respectively. Scale bars $=5 \mathrm{~mm}$. 


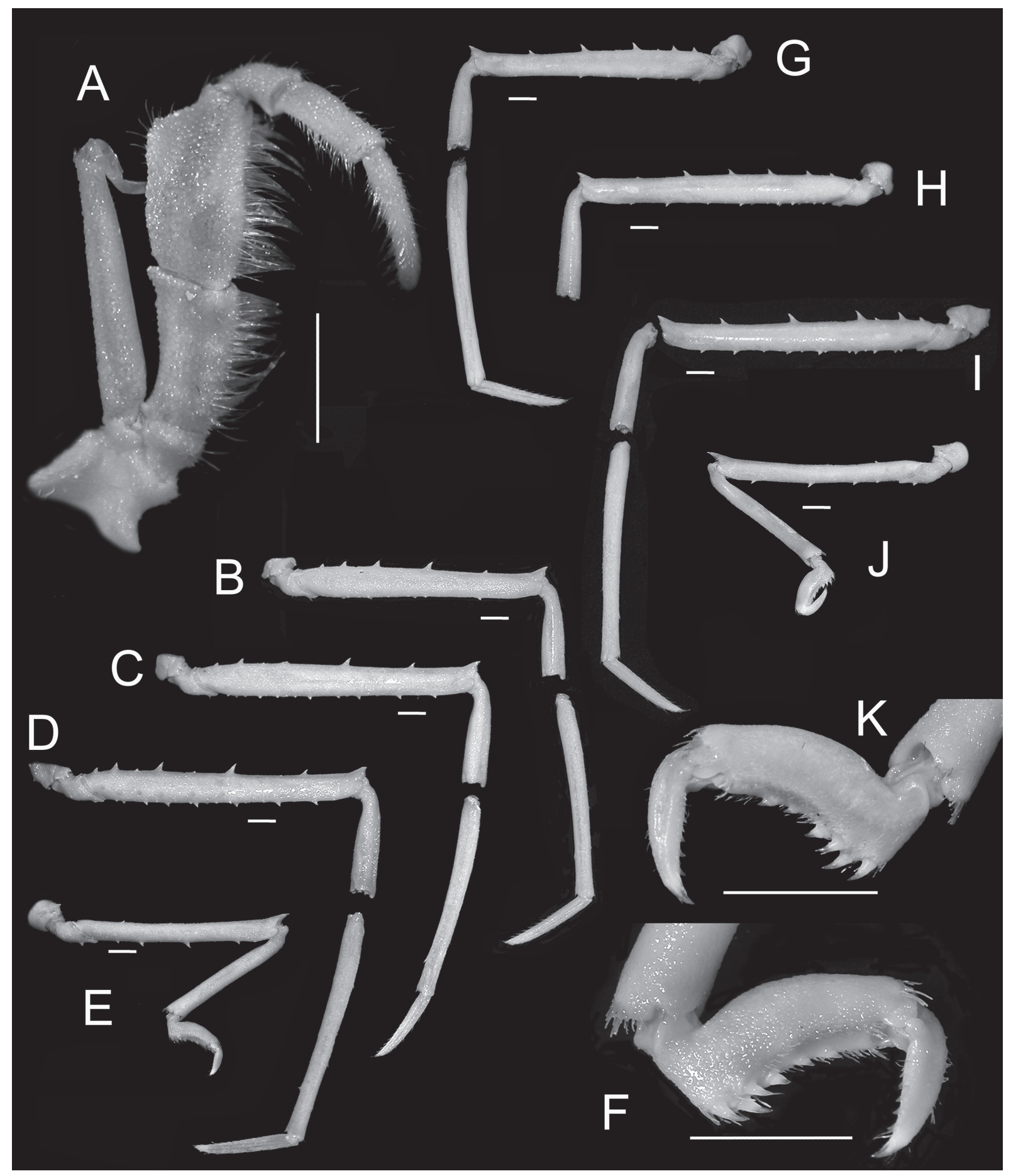

Fig. 11. Moloha alisae Guinot \& Richer de Forges, 1995. Holotype, đ̊ (cl $36.1 \mathrm{~mm}$, cw $29.7 \mathrm{~mm}$ ) (MNHN-IU-2008-11077), Seychelles. A. Right third maxilliped. B-E. Right P2-P5, respectively. F. Right P5 subchelate dactylus and propodus. G-J. Left P2-P5, respectively. K. Left P5 subchelate dactylus and propodus. Scale bars $=5 \mathrm{~mm}$. 
NG P.K.L. \& KUMAR A.B., Species of Moloha from the western Indian Ocean

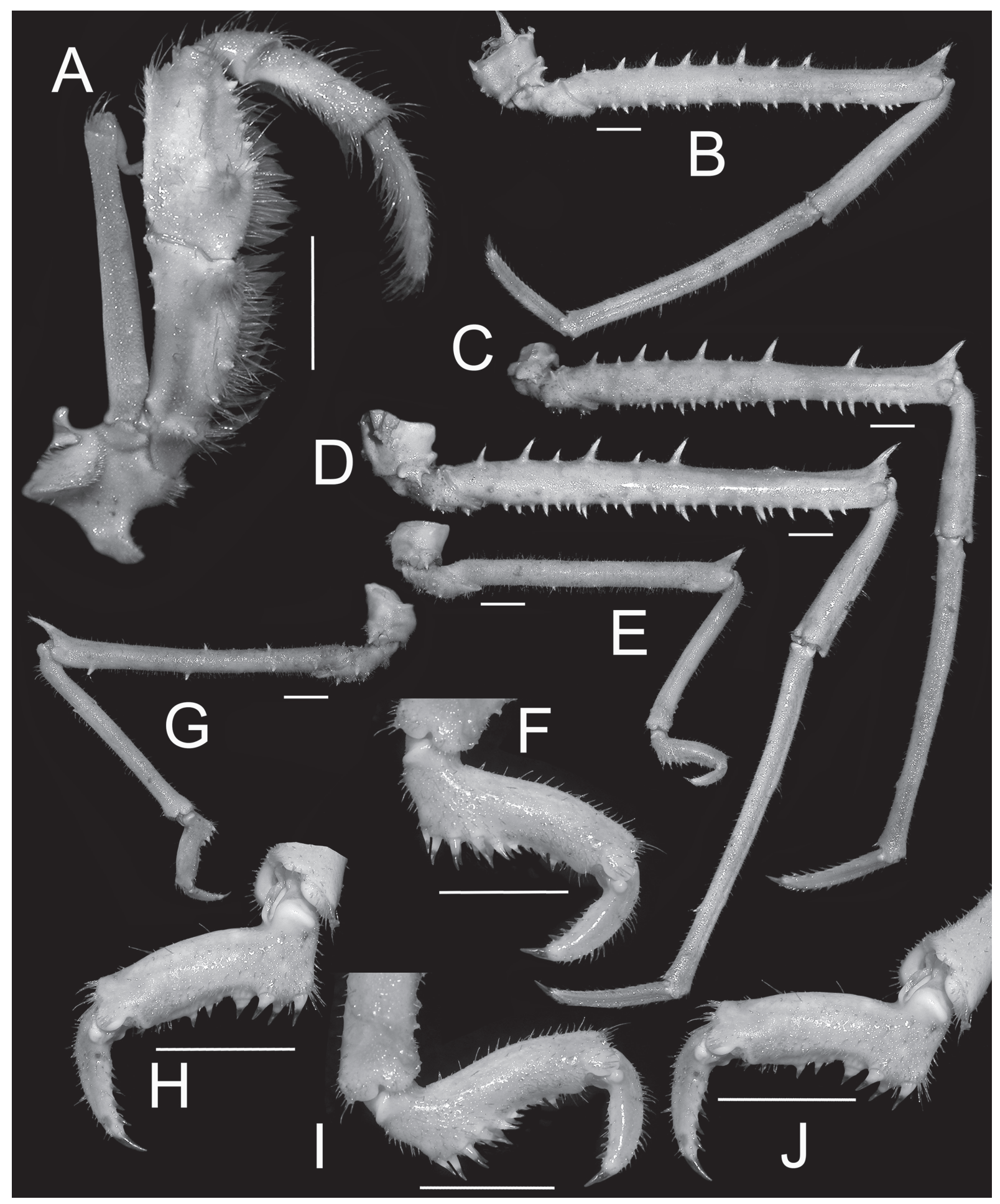

Fig. 12. Moloha alisae Guinot \& Richer de Forges, 1995. A-H. $ð(\mathrm{cl} 67.7 \mathrm{~mm}$, cw $56.2 \mathrm{~mm})$ (ZRC 2008.1250a), South Africa. I-J. ô (cl $67.5 \mathrm{~mm}$, cw $56.5 \mathrm{~mm}$ ) (ZRC 2008.1250b), South Africa. A. Right third maxilliped. B-E. Right P2-P5, respectively. F, I. Right P5 subchelate dactylus and propodus. G. Left P5. H, J. Left P5 subchelate dactylus and propodus. Scale bars $=10 \mathrm{~mm}$. 


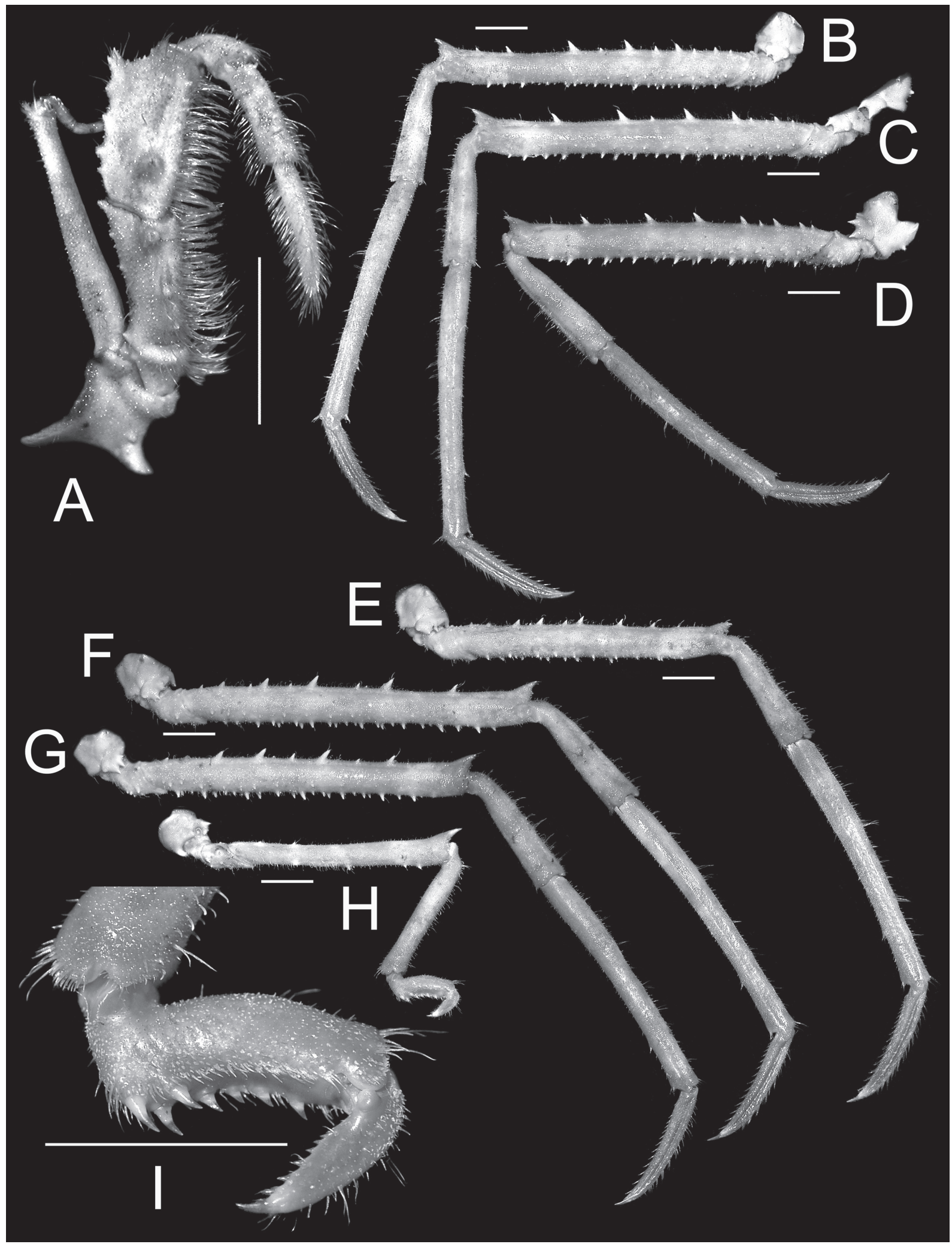

Fig. 13. Moloha tumida sp. nov. Holotype, $\widehat{\partial}$ ( $\mathrm{cl} 55.7 \mathrm{~mm}$, $\mathrm{cw} 50.6 \mathrm{~mm}$ ) (DABFUK), Kerala, India. A. Right third maxilliped. B-D. Left P2-P4, respectively. E-H. Right P2-P5, respectively. I. Right P5 subchelate dactylus and propodus. Scale bars $=10 \mathrm{~mm}$. 
NG P.K.L. \& KUMAR A.B., Species of Moloha from the western Indian Ocean

Moloha tumida sp. nov.

urn:1sid:zoobank.org:act:25B20CDD-06DA-4A14-BB61-1F7954ED6357

Figs 1B, 3B, 4C, 5B, 9, 13, 14B, 15D-G, 17B

\section{Diagnosis}

Carapace with pseudorostral and supraocular spines long, subequal; supraocular spine with distinct submedian accessory spine; gastric region with many sharp granules in addition to 3 major spines; branchial regions distinctly inflated; subhepatic region swollen, with 2 large dorsal and 3 small ventral spines; protogastric region with 2 major spines; basal antennal spine acute; P2-P4 long, slender,

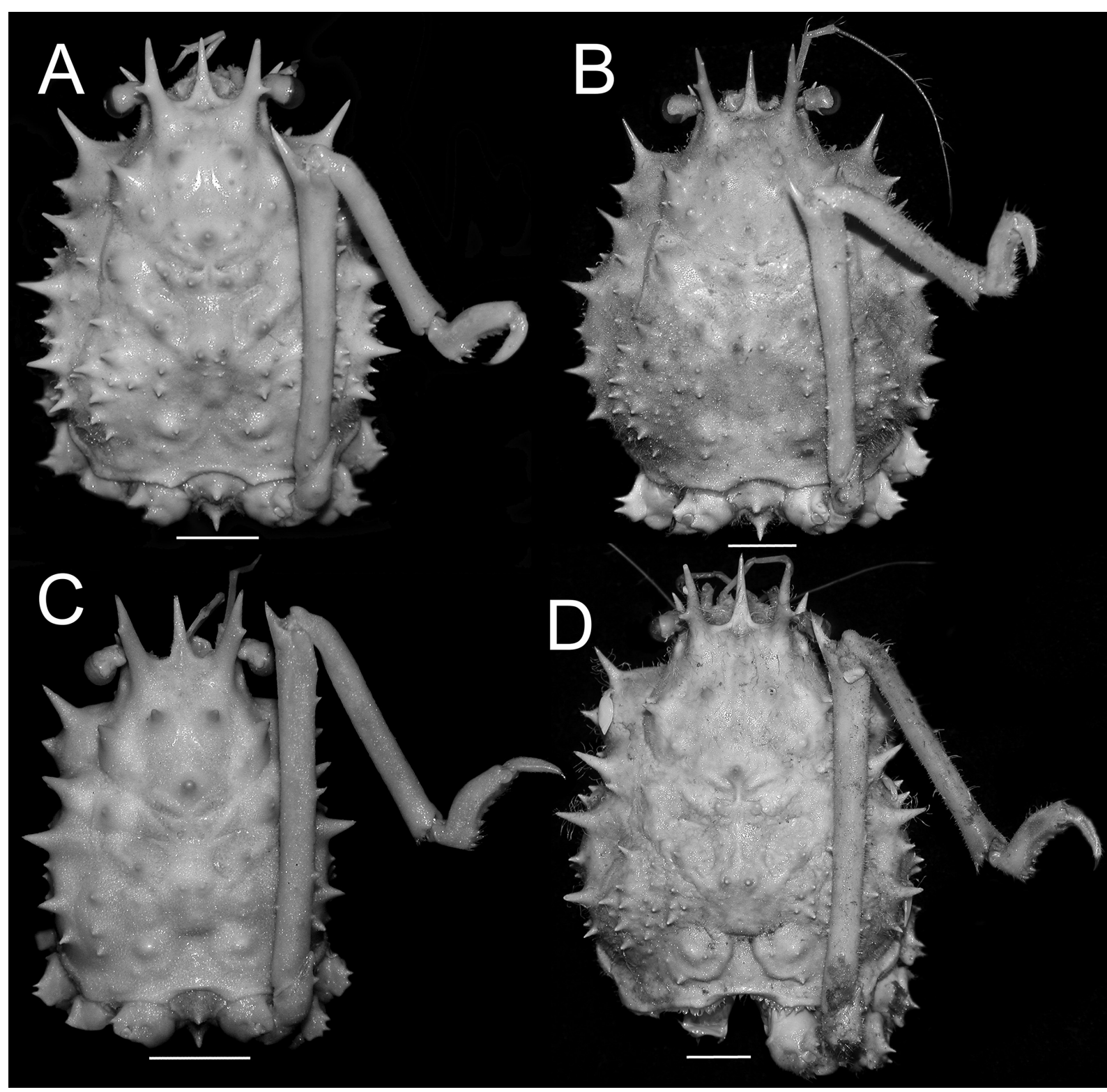

Fig. 14. Dorsal view of carapace showing position of folded right P5. A. Moloha grandperrini Guinot \& Richer de Forges, 1995. Holotype, ${ }^{\lambda}$ (cl $46.5 \mathrm{~mm}$, cw $39.0 \mathrm{~mm}$ ) (NHM 1948.9.7.27), Maldives. B. Moloha tumida sp. nov. Holotype, ô (cl $55.7 \mathrm{~mm}$, cw $50.6 \mathrm{~mm}$ ) (DABFUK), Kerala, India. C. Moloha alisae Guinot \& Richer de Forges, 1995. Holotype, §̊ (cl $36.1 \mathrm{~mm}$, cw $29.7 \mathrm{~mm}$ ) (MNHNIU-2008-11077), Seychelles. D. Moloha alisae Guinot \& Richer de Forges, 1995. О̊ (cl 67.7 mm, cw $56.2 \mathrm{~mm}$ ) (ZRC 2008.1250a), South Africa. Scale bars $=10 \mathrm{~mm}$. 
subcylindrical, merus with 8-10 spines on dorsal margin, outer surface with 1-13 small spines, ventral margin with 19-28 spines; P5 with 2 spines on dorsal margin, 2 small spines on outer surface, 4 spines on ventral margin, subchelate structure stout, propodus with 3 large basal spines, rest of margin with distinct, closely arranged, similarly sized spines. G1 stout, short, groove on ventral surface submedian, dorso-median surface flat, distal part less rounded, opening large, auriculiform, directed towards median part of sternum.

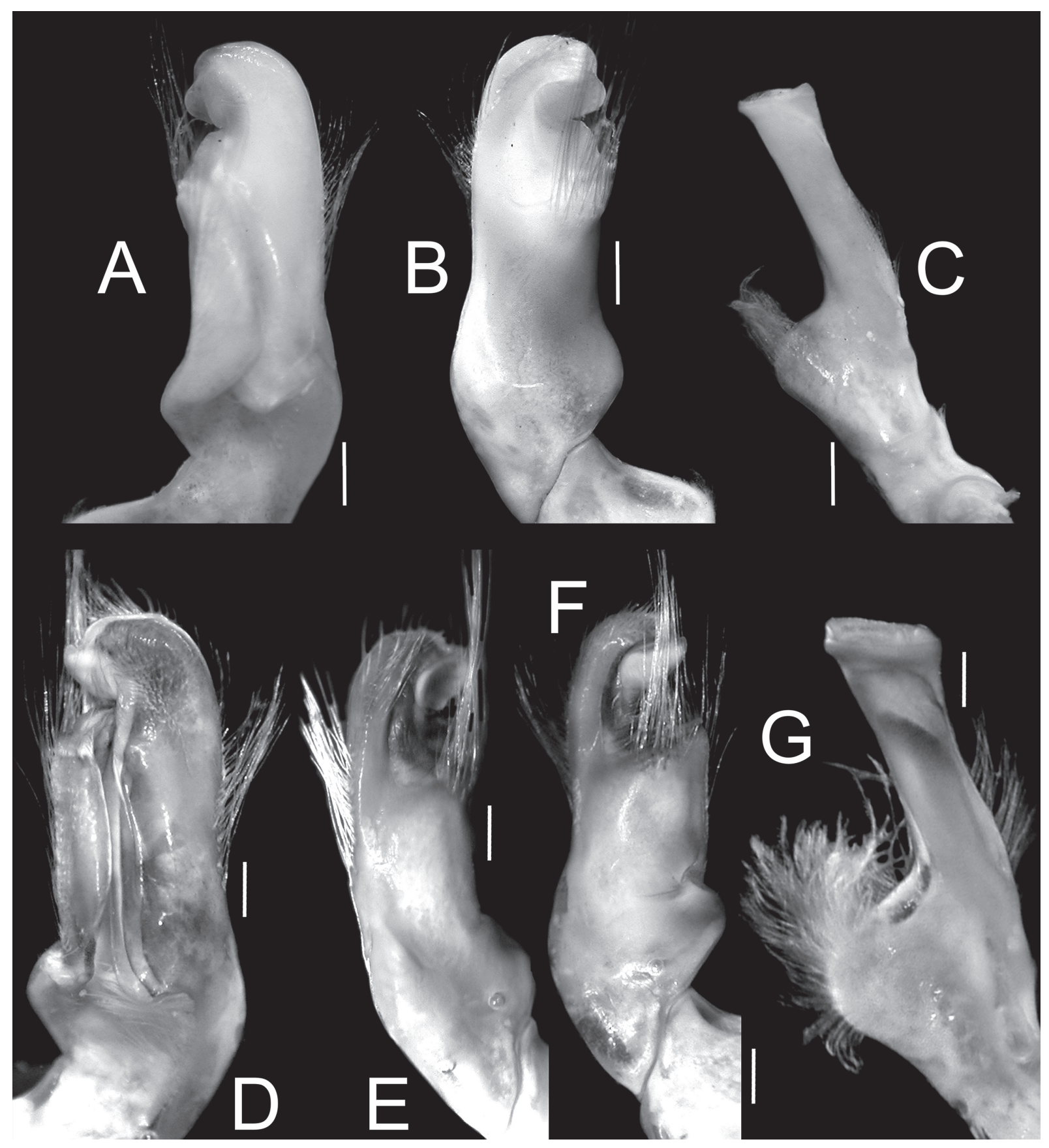

Fig. 15. Gonopods. A-C. Moloha grandperrini Guinot \& Richer de Forges, 1995. Holotype, ô (cl $46.5 \mathrm{~mm}$, cw $39.0 \mathrm{~mm}$ ) (NHM 1948.9.7.27), Maldives. D-G. Moloha tumida sp. nov. Holotype, ô (cl $55.7 \mathrm{~mm}$, cw $50.6 \mathrm{~mm}$ ) (DABFUK), Kerala, India. - A, D. Ventral view of left G1. B, F. Dorsal view of left G1. E. Outer-lateral view of left G1. C, G. Left G2. Scale bars $=1 \mathrm{~mm}$. 
NG P.K.L. \& KUMAR A.B., Species of Moloha from the western Indian Ocean

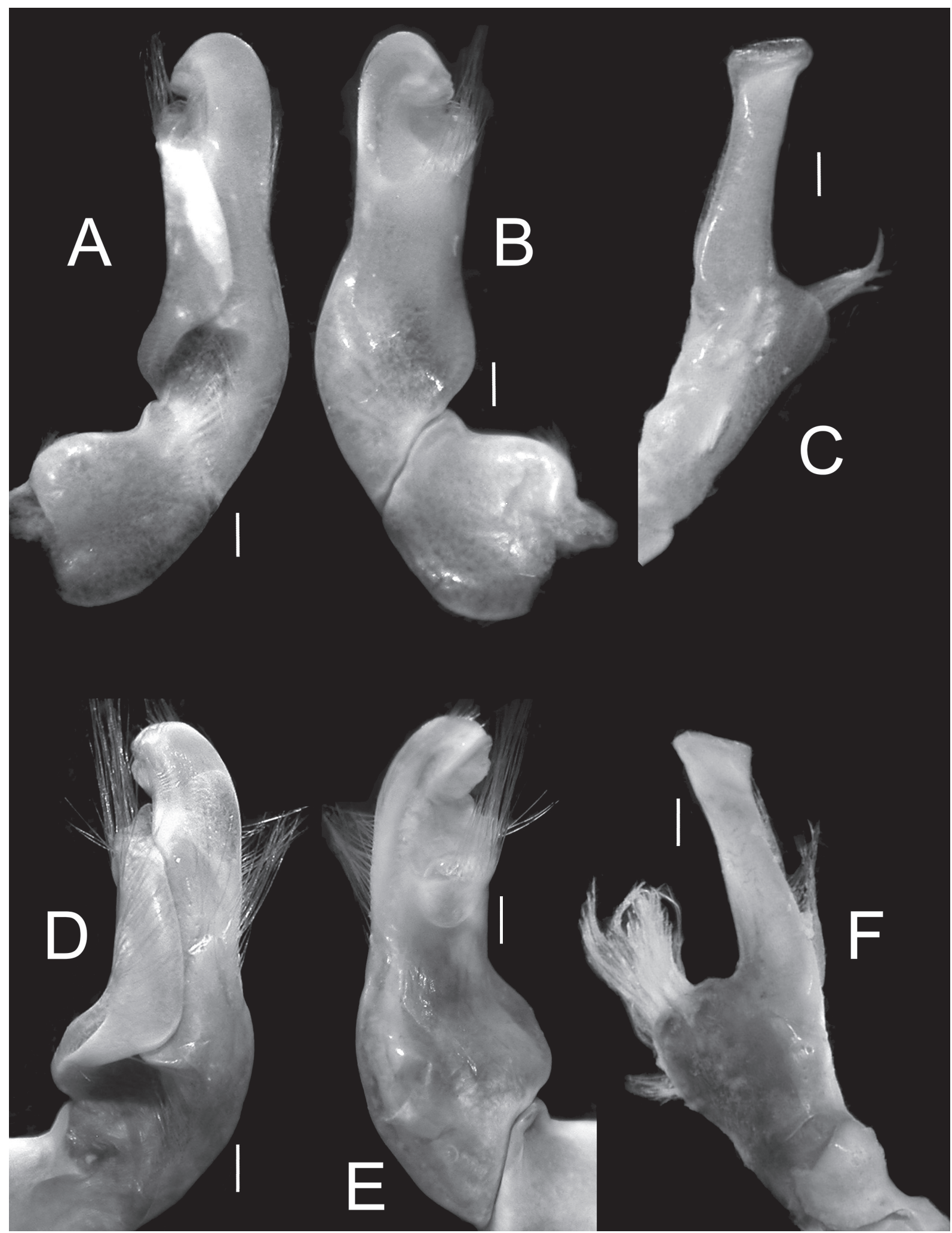

Fig. 16. Gonopods. A-C. Moloha alisae Guinot \& Richer de Forges, 1995. Holotype, ठ̊ (cl $36.1 \mathrm{~mm}$, cw 29.7 mm) (MNHN-IU-2008-11077), Seychelles. D-F. Moloha alisae Guinot \& Richer de Forges, 1995. O (cl $67.7 \mathrm{~mm}$, cw $56.2 \mathrm{~mm}$ ) (ZRC 2008.1250a), South Africa. - A, D. Ventral view of left G1. B, E. Dorsal view of left G1. C, F. Left G2. Scale bars $=1 \mathrm{~mm}$. 

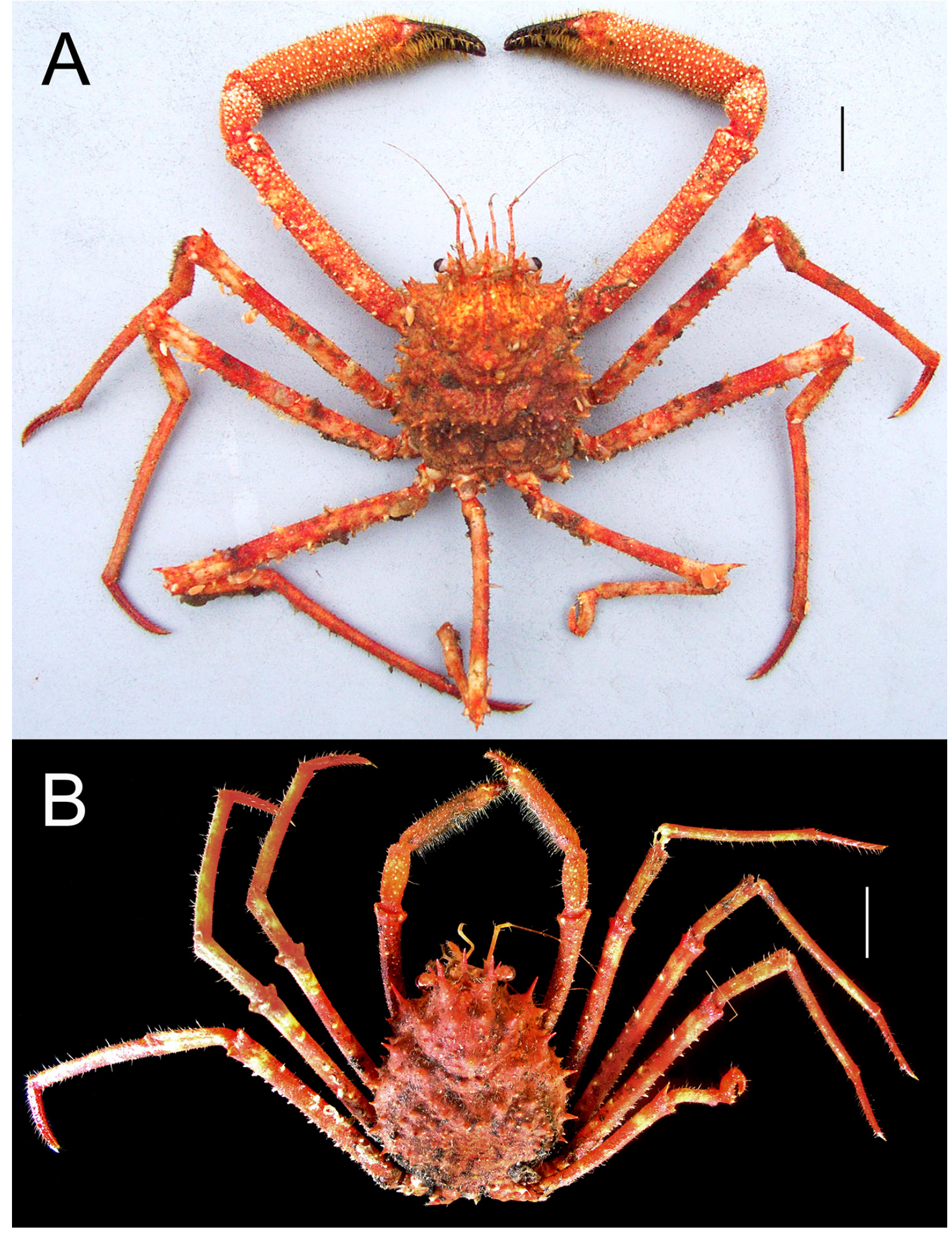

Fig. 17. Colour in life, dorsal view. A. Moloha alisae Guinot \& Richer de Forges, 1995. $0^{\Uparrow}$ (cl $67.7 \mathrm{~mm}$, cw $56.2 \mathrm{~mm}$ ) (ZRC 2008.1250a), South Africa [photograph by Sean Fennessy]. B. Moloha tumida sp. nov. Holotype, ô (cl $55.7 \mathrm{~mm}$, cw $50.6 \mathrm{~mm}$ ) (DABFUK), India [photograph by Biju Kumar]. Scale bars $=20 \mathrm{~mm}$. 
NG P.K.L. \& KUMAR A.B., Species of Moloha from the western Indian Ocean

\section{Etymology}

The species is named after the relatively swollen carapace.

\section{Material examined}

\section{Holotype}

INDIA: ô (tcl 64.4 mm, cl 55.7 mm, tcw $56.1 \mathrm{~mm}$, cw 50.6 mm), Kerala, 300-350 m, 3 Dec. 2014 (DABFUK).

\section{Description}

Medium-sized species, spiny on carapace, appendages, chelipeds and ambulatory legs (Figs 1B, 3B, 4C, 5B, 13, 14B). Dorsal surface of carapace with deep grooves, well marked regions (Figs 1B, 3B, $4 \mathrm{C}, 5 \mathrm{~B}, 14 \mathrm{~B}$ ). Pseudorostral spine simple, as long as or slightly longer than supraorbital spines (Figs 1B, 3B, 14B). Proepistome with sharp spine. Supraocular spine long, straight, with prominent laterally directed accessory spine on anterior third (Figs 1B, 3B, 4C, 5B, 14B); infraorbital spine long, gently curved outwards, about $2 / 3$ length of supraorbital spine, visible in dorsal view (Figs $4 \mathrm{C}, 5 \mathrm{~B}$ ); buccal spine prominent, just visible in dorsal view (Figs 4C, 5B); basal antennal spine sharp, acute (Figs 4C, 5B); protogastric region with 2 major spines and smaller spinules posterior and lateral to them (Figs 1B, 2B, 5B, 14B); mesogastric region with 1 large median spine (Figs 1B, 2B, 5B, 14B); mesobranchial region with 5 or 6 large, laterally directed spines and numerous spinules behind them (Figs 1B, 2B, 5B, 14B); subhepatic region swollen, with 2 large dorsal spines, 1 median spine and 2 small ventral spines (Figs 1B, 2B, 4C, 5B, 14B); anterolateral spine distinct, pointing obliquely anteriorly, with smaller spine below it (Figs 1B, 2B, 5B, 14B); posterolateral spines distinct, 3 largest laterally directed, first largest, with many spinules between them (Figs 1B, 2B, 5B, 14B); cardiac region small, with 1 short spine (Figs 1B, 2B, 4C, 5B, 14B). Cervical groove shallow, but clearly visible (Figs 1B, 2B, 14B); transverse cardio-intestinal groove shallow (Figs 1B, 2B, 14B). Posterior carapace margin strongly concave; lateral margins of branchiostegite almost smooth (Figs 1B, 2B, 14B). Eyes short; podophthalmite short, stout; basophthalmite slender, elongate; cornea bulbous (Figs 1B, 2B, 4C, 5B, 14B). Antennules with a swollen basal article, other articles long, slender, with elongate flagellum (Fig. 4C). Antennae short, first article with large urinary article (Figs 4C, 5B). Epistome truncate; posterior margin gently sinuous, with median part weakly triangular, lateral parts gently concave (Fig. 4C). Third maxilliped subpediform, elongated; inner margins lined with dense, long setae; basis-ischium with 4 submedian tubercles; merus with 1 large subproximal tubercle, anterolateral margin dentate; carpus short, unarmed; propodus and dactylus elongated, unarmed (Fig. 13A).

Cheliped relatively long, slender, spiny (Figs 1B); coxa with 2 short spines; ischium subtrigonal in crosssection, with 3-7 short spines; merus with 3 rows of short or long spines: dorsal row with 17-19 spines, outer surface with 12 or 13 spines, ventral margin with 14-18 spines (Figs 1B, 9D); carpus elongate, outer surface granulated, not spinose (Figs 1B, 9D-E). Palm slender, covered with small granules and setae, those on inner surface denser and longer; fingers shorter than palm, with hooked tips, pigmented throughout most of length except near base, that of pollex not extending substantially into palm; cutting edges blade-like; dactylus with 1 low subproximal tubercle (Figs 1B, 9E-F).

Ambulatory legs long, slender; meri subcylindrical; P3 longest (Figs 1B, 13B-H). P2 coxa with 3 spines; ischium with 4 short spines; merus with 3 rows of short or long spines: dorsal row with 9 or 10 spines, outer surface with 1-13 spines, ventral margin with 19-21 spines (Fig. 13B, E). P3 coxa with 3 spines; ischium with 4-7 short spines; merus with 3 rows of short or long spines: dorsal row with 9 spines, outer surface with 10-13 spines, ventral margin with 20-25 spines (Fig. 13C, F). P4 coxa with 2 or 3 spines; ischium with 3-6 short spines; merus with 3 rows of short or long spines: dorsal row with 8 spines, outer surface with 11 spines, ventral margin with 26-28 spines (Fig. 13D, G). P5 coxa with 1 spine; ischium with 
2 short spines; merus with 3 rows of short or long spines: dorsal row with 2 spines, outer surface with 2 spines, ventral margin with 4 spines; carpus elongate, unarmed; propodus and dactylus forming subchelate structure; propodus curved, relatively shorter, flexor margin with 3 large, curved spines and 4 or 5 smaller spines anterior to it in a row, dactylus curved with 6-9 small spines on flexor margin (Fig. 13H-I).

Male pleon ovate, completely covering thoracic sternal surface; telson pentagonal, with distal half triangular, with sharp tip, basal part quadrate, lateral margin convex to distinctly convex (Fig. 9AB); somite 6 trapezoidal, with deeply concave lateral margins, distal median margin with prominent spine (Fig. 9A-B); somites 4 and 5 subquadrate, with lateral margins expanded, triangular, somite 5 distal median margin with distinct tubercle, somite 4 with median tubercle (Fig. 9B); somites 2 and 3 trapezoidal, with long median spine; somite 1 short, with sharp median tubercle (Fig. 9B). Sternopleonal cavity deep, smooth; thoracic sternites 1-5 without median longitudinal line, suture between sternites 5 and 6 shallow, complete; pair of partially flattened prominences (homolid button, cf. Guinot \& Bouchard 1998: 635, fig. 9c) on sternite 4 at margin of sternopleonal cavity, fits into pair of sockets on internal marginal surface of somite 6 (Fig. 9C).

G1 short, stout, distal part rounded; opening directed towards median part of thoracic sternum; groove submedian; dorso-median surface flat; distal part less rounded; opening auriculiform (Figs 9C, 15D-F); marginal and submarginal surfaces along distal part with long setae (Fig. 15D-F). G2 stout, as long as G1, basal part dilated, with long setae; distal part cup-like (Fig. 15G).

\section{Colour}

In life, the carapace and chelipeds are red; the ambulatory legs are red with patches of white and the ventral surfaces are dirty white (Fig. 17B).

\section{Distribution}

The species is known only from southwestern India.

\section{Remarks}

See the Discussion section.

\section{Discussion}

Guinot \& Richer de Forges (1995) recognised three species of Moloha from the western Indian Ocean: M. alcocki (Stebbing, 1920), M. alisae Guinot \& Richer de Forges, 1995, and M. grandperrini Guinot \& Richer de Forges, 1995. Serène \& Lohavanijaya (1973) described Paromola alcocki faughni from the South China Sea, but this species was recently synonymised with Paromola macrochira Sakai, 1961 (see Ng 2015).

As discussed at length by Guinot \& Richer de Forges (1995: 380), Moloha alcocki (Stebbing, 1920) s. str. is a very distinct species, markedly different from all congeners in its laterally flattened ambulatory meri (Guinot \& Richer de Forges 1995: figs 29a). In addition, its carapace is distinctly longitudinally rectangular, with the lateral margins straight (Guinot \& Richer de Forges 1995: figs 29a-b). The ischium of the third maxilliped also bears five tubercles (Guinot \& Richer de Forges 1995: fig. 30B) but on M. grandperrini and M. alisae it only has four (Figs 10A, 11A, 12A). Moloha alcocki is known only from South Africa so far. Specimens which have been identified as "M. alcocki" by other authors have since been referred to M. majora (Kubo, 1936) and M. grandperrini Guinot \& Richer de Forges, 1995 (Guinot \& Richer de Forges 1995: 380). Guinot \& Richer de Forges (1995) described two new species from the western Indian Ocean which were superficially similar to M. alcocki but differed in having subcylindrical ambulatory meri - M. alisae and M. grandperrini. 
NG P.K.L. \& KUMAR A.B., Species of Moloha from the western Indian Ocean

Table 1. Spine counts on margins and surfaces of the meri of P1-P5 of Moloha species. The counts are given in the following order: dorsal margin/outer surface/ventral margin. L and $\mathrm{R}$ are for left and right sides, respectively.

\begin{tabular}{|c|c|c|c|c|c|}
\hline Specimen & P1 & P2 & P3 & P4 & P5 \\
\hline 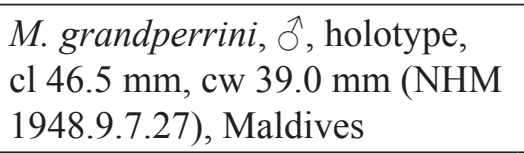 & $\begin{array}{l}\text { L: } 7 / 2 / 13 \\
\text { R: } 6 / 5 / 10\end{array}$ & $\begin{array}{l}\mathrm{L}: 7 / 3 / 21 \\
\mathrm{R}: 7 / 4 / 19\end{array}$ & $\begin{array}{l}\mathrm{L}: \text { missing } \\
\mathrm{R}: 7 / 7 / 19\end{array}$ & $\begin{array}{l}\mathrm{L}: 6 / 10 / 15 \\
\mathrm{R}: 7 / 8 / 17\end{array}$ & $\begin{array}{l}\mathrm{L}: 1 / 4 / 5 \\
\mathrm{R}: 2 / 4 / 4\end{array}$ \\
\hline $\begin{array}{l}\text { M. alisae, O, holotype, cl } 36.1 \\
\text { mm, cw } 29.7 \text { mm (MNHN- } \\
\text { IU-2008-11077), Seychelles }\end{array}$ & $\begin{array}{l}\text { L: } 5 / 2 / 4 \\
\mathrm{R}: 5 / 3 / 3\end{array}$ & $\begin{array}{l}\text { L: } 8 / 3 / 9 \\
\mathrm{R}: 6 / 3 / 8\end{array}$ & $\begin{array}{l}\text { L: } 7 / 4 / 12 \\
\text { R: } 8 / 4 / 13\end{array}$ & $\begin{array}{l}\text { L: } 6 / 7 / 16 \\
\text { R: } 8 / 8 / 14\end{array}$ & $\begin{array}{l}\mathrm{L}: 2 / 2 / 4 \\
\mathrm{R}: 2 / 2 / 5\end{array}$ \\
\hline $\begin{array}{l}\text { M. alisae, ठ̂, cl } 67.7 \mathrm{~mm}, \mathrm{cw} \\
56.2 \mathrm{~mm}(\text { ZRC } 2008.1250 \mathrm{a}), \\
\text { South Africa }\end{array}$ & $\begin{array}{c}\text { L: 13/-/12 } \\
\text { R: 15/-/6 }\end{array}$ & $\begin{array}{l}\text { L: } 8 / 9 / 24 \\
\text { R: } 7 / 1 / 20\end{array}$ & $\begin{array}{l}\mathrm{L}: 8 / 8 / 26 \\
\mathrm{R}: 8 /-/ 21\end{array}$ & $\begin{array}{l}\mathrm{L}: 7 / 5 / 24 \\
\mathrm{R}: 6 / 5 / 23\end{array}$ & $\begin{array}{l}\mathrm{L}: 3 / 3 / 2 \\
\mathrm{R}: 1 / 4 / 2\end{array}$ \\
\hline $\begin{array}{l}\text { M. alisae, ठ̀, cl } 67.5 \mathrm{~mm}, \mathrm{cw} \\
56.5 \mathrm{~mm}(\mathrm{ZRC} 2008.1250 \mathrm{~b}), \\
\text { South Africa }\end{array}$ & $\begin{array}{l}\mathrm{L}: 16 /-/ 12 \\
\mathrm{R}: 16 /-/ 15\end{array}$ & $\begin{array}{l}\mathrm{L}: 9 / 3 / 22 \\
\mathrm{R}: 9 / 3 / 24\end{array}$ & $\begin{array}{l}\mathrm{L}: 8 / 5 / 26 \\
\mathrm{R}: 9 / 3 / 21\end{array}$ & $\begin{array}{l}\mathrm{L}: 10 / 4 / 24 \\
\mathrm{R}: 7 / 6 / 22\end{array}$ & $\begin{array}{l}\mathrm{L}: 1 / 1 / 4 \\
\mathrm{R}: 3 / 4 / 2\end{array}$ \\
\hline $\begin{array}{l}\text { M. tumida sp. nov., đ̂, holotype, } \\
\text { cl } 55.7 \mathrm{~mm}, \mathrm{cw} 50.6 \mathrm{~mm} \\
\text { (DABFUK), India }\end{array}$ & $\begin{array}{l}\text { L: 17/13/18 } \\
\text { R: 19/12/14 }\end{array}$ & $\begin{array}{c}\text { L: 9/1/19 } \\
\text { R: 10/13/21 }\end{array}$ & $\begin{array}{l}\mathrm{L}: 9 / 10 / 20 \\
\mathrm{R}: 9 / 13 / 25\end{array}$ & $\begin{array}{l}\mathrm{L}: 8 / 11 / 28 \\
\mathrm{R}: 8 / 11 / 26\end{array}$ & $\begin{array}{c}\mathrm{L}: 2 / 2 / 4 \\
\mathrm{R}: \text { missing }\end{array}$ \\
\hline
\end{tabular}

In describing M. alisae from a single male (cl $40.6 \mathrm{~mm}$, cw $29.7 \mathrm{~mm}$ ) from the Seychelles, Guinot \& Richer de Forges $(1995: 379,391)$ noted that it was close to M. grandperrini, which was described also from a solitary male (cl $46.5 \mathrm{~mm}$, cw $39.0 \mathrm{~mm}$ ) from the Maldives. They argued that M. alisae differed from $M$. grandperrini in having the dorsal surfaces of the carapace relatively less convex and swollen, the surfaces between the large spines on the gastric region of the carapace are smooth (covered with small sharp granules in $M$. grandperrini), the spines lining the ventral margin of the ambulatory merus of P2-P4 are fewer and spaced further apart, and the distal edge of the merus of P5 reaches the base of the pseudorostral spine when it is folded anteriorly (reaches only the protogastric region in $M$. grandperrini). As discussed earlier under M. alisae, the number and strength of spines on P2-P4 may not be a useful character as it is size-associated (see also Table 1).

The two large specimens from South Africa here referred to M. alisae (ZRC 2008.1250) possess almost all the diagnostic characters stated by Guinot \& Richer de Forges (1995) for the species (see discussion for this species). Despite their much larger sizes (cl $67.7 \mathrm{~mm}$, cw $56.2 \mathrm{~mm}$; cl $67.5 \mathrm{~mm}$, cw $56.5 \mathrm{~mm}$ ), both have carapaces that appear to be somewhat more rectangular in form when viewed dorsally (Figs 2B, 3D, 14D) compared to that of $M$. grandperrini, with the lateral branchial margins of the latter species slightly more convex (Figs 1A, 3A, 14A). The gastric region of M. grandperrini, other than armed with three major spines (two anteriorly and one posterior), also has several distinct sharp granules on the surface (Figs 1A, 3A, 14A). In M. alisae, the surfaces of the gastric region are completely smooth, other than for the three spines (Figs 2, 3C-D, 14C-D). Regardless of size, the ambulatory legs of M. alisae are also proportionately longer, notably in the lengths of the propodi (Figs 2, 11B-D, G-I, 12B-D) (relatively shorter in M. grandperrini; Figs 1A, 10B-D, G-H); and for P5, the distal edge of the merus (not including the distal spine) reaches the base of the pseudorostrum when it is folded anteriorly, even in the largest specimen (Fig. 14C-D) (reaches only to the anterior edge of the protogastric region in M. grandperrini; Fig. 14A). Another marked difference not mentioned by Guinot \& Richer de Forges 
(1995) is the depth of the transverse cardio-intestinal groove. In M. alisae, this groove is very deep and distinct (Figs 2, 3C-D, 14C-D), and is evident even on the small holotype male (Figs 2A, 3C, 14C, Guinot \& Richer de Forges 1995: fig. 29f). In M. grandperrini, the transverse cardio-intestinal groove is relatively more shallow (Figs 1A, 3A, 14A). Another character differentiating the species is the form of the subchelate process of the P5. In M. alisae, the propodus is more elongate and other than the four major spines at the proximal edge, the spines on the rest of the flexor margin are spaced further apart and relatively smaller (Fig. 11E-F, J-K) (see also Guinot \& Richer de Forges 1995: fig. 51i). In M. grandperrini, the propodus is proportionately shorter and the smaller spines on the inner margin are relatively larger and close to each other (Fig. 10E-F, I). The G1s of the two species are superficially similar, but in M. grandperrini the distalmost part is more rounded (Fig. 15A-B) than it is in M. alisae (Fig. 16A-B, D-E).

Moloha tumida sp. nov. is easily distinguished from M. alisae and M. grandperrini in its prominently more convex and swollen branchial regions (Figs 1B, 3B, 5B, 14B). In addition, the basal antennal spine is acute in M. tumida sp. nov. (Fig. 5B), but is relatively broader and stouter in M. alisae and M. grandperrini (Fig. 5A, C-D). The carapace of $M$. tumida sp. nov. is similar to that of M. grandperrini in possessing secondary small tubercles on the gastric region and in having the cardio-intestinal groove very shallow and barely visible (Figs 1B, 3B, 14B). The ambulatory legs of $M$. tumida sp. nov. are proportionately the shortest among the three species, notably in the length of the propodus (Figs 1B, 13B-D, E-G); this also applies to the P5 in which, when folded over the carapace, the distal edge (excluding the spine) only reaches to the proximal part of the subhepatic region (Fig. 14B). There are no obvious differences in the degree of spination on the meri of P2-P5 in adult specimens of these species (Table 1). The holotype male of M. alisae is small and is a young male, and its P2-P5 are relatively less spinate (Table 1), but this is almost certainly because of its small size. The subchelate structure of M. tumida sp. nov. is similar in that of M. grandperrini, differing from M. alisae in the same features (see earlier). Although the G1 of M. tumida sp. nov. is superficially similar to that of M. alisae and $M$. grandperrini, it differs in having the ventral groove closer to the inner margin (Fig. 15D) (ventral groove distinctly median in M. alisae and M. grandperrini; Figs 15A, 16A, D), the surface of the median part of the G1 (when viewed dorsally) almost flat (Fig. 15F) (surface concave on the median surface in M. alisae and $M$. grandperrini; Fig. 15B, 16B, E), and the distal opening distinctly more flared and auriculiform (Fig. 15D-E) (more rounded or flap-like in M. alisae and M. grandperrini; Figs 15A-B, 16A-B, D-E).

\section{Acknowledgements}

Thanks are due to Paul Clark (NHM) and Paula Martin-Lefevre (MNHN) for arranging the loan of the types of Moloha grandperrini and M. alisae, respectively, to the first author for study. The first author is also grateful to Sean Fennessy (Oceanographic Research Institute, South Africa) for sending him the South African material and his photograph of the specimen. The many helpful suggestions from Danièle Guinot and Bertrand Richer de Forges are much appreciated.

\section{References}

Ahyong S.T., Naruse T., Tan S.H. \& Ng P.K.L. 2009. Part II. Infraorder Brachyura: Sections Dromiacea, Raninoida, Cyclodorippoida. In: Chan T.-Y., Ng P.K.L., Ahyong S.T. \& Tan S.H. (eds) Crustacean Fauna of Taiwan: Brachyuran Crabs, Vol. I: 27-180. National Taiwan Ocean University, Keelung, Taiwan.

Barnard K.H. 1946. Descriptions of new species of South African decapod Crustacea, with notes on synonymy and new records. Annals and Magazine of Natural History, Series 11, 13 (102): 361-392. http://dx.doi.org/10.1080/00222934608654562 
NG P.K.L. \& KUMAR A.B., Species of Moloha from the western Indian Ocean

Evenhuis N.L. 2003. Publication and dating of the journals forming the Annals and Magazine of Natural History and the Journal of Natural History. Zootaxa 385: 1-68.

Garassino A. 2009. The thoracic sternum and spermatheca in the extant genera of the family Homolidae De Haan, 1839 (Crustacea, Decapoda, Brachyura). Memorie della Società Italiana di Scienze Naturali e del Museo Civico di Storia Naturale di Milano 36 (3): 1-80.

Gordon I. 1950. Crustacea Dromiacea. Part I: Systematic account of the Dromiacea collected by the "John Murray" Expedition. Part II. The morphology of the spermatheca in certain Dromiacea. Scientific Reports of the John Murray Expedition 1933-34 9 (3): 201-253.

Guinot D. \& Bouchard J.M. 1998. Evolution of the abdominal holding systems of brachyuran crabs (Crustacea, Decapoda, Brachyura). Zoosystema 20 (4): 613-694.

Guinot D. \& Richer De Forges B. 1995. Crustacea Decapoda Brachyura: Révision de la famille des Homolidae de Haan, 1839. In: Crosnier A. (ed.) Résultats des Campagnes MUSORSTOM, Vol. 13. Mémoires du Muséum national d'Histoire naturelle 163:283-517. Muséum national d'Histoire naturelle, Paris.

Kensley B.F. 1980. Decapod and isopod crustaceans from the west coast of Southern Africa, including seamounts Verna and Tripp. Annals of the South African Museum 83 (2): 13-32. Available from http:// biodiversitylibrary.org/page/40753627 [accessed 6 Dec. 2015]

Ng P.K.L. 2015. Paromola alcocki faughni Serène \& Lohavanijaya, 1973: a junior synonym of Paramola macrochira Sakai, 1961 (Decapoda, Brachyura, Homolidae). Crustaceana 88 (12-14): 1447-1456. http://dx.doi.org/10.1163/15685403-00003496

Ng P.K.L., Guinot D. \& Davie P.J.F. 2008. Systema Brachyurorum: Part I. An Annotated Checklist of Extant Brachyuran Crabs of the World. Raffles Bulletin of Zoology, Supplement 17: 1-286.

Richer De Forges B. \& Ng P.K.L. 2007. New records and new species of Homolidae De Haan, 1839, from the Philippines and French Polynesia (Crustacea: Decapoda: Brachyura). Raffles Bulletin of Zoology, Supplement 16: 29-45.

Richer De Forges B. \& Ng P.K.L. 2008. New western Pacific records of Homolidae De Haan, 1839, with descriptions of new species of Homolochunia Doflein, 1904, and Latreillopsis Henderson, 1888 (Crustacea: Decapoda: Brachyura). Zootaxa 1967: 1-35.

Serène R. \& Lohavanijaya P. 1973. The Brachyura (Crustacea: Decapoda) collected by the Naga Expedition, including a review of the Homolidae. In: Brinton E., Newman W.A. \& Wooster W.S. (eds) Scientific Results of Marine Investigations of the South China Sea and the Gulf of Thailand, 1959-1961. Naga Report 4 (4): 1-187.

Manuscript received: 7 October 2015

Manuscript accepted: 28 October 2015

Published on: 17 December 2015

Topic editor: Rudy Jocqué

Desk editor: Kristiaan Hoedemakers

Printed versions of all papers are also deposited in the libraries of the institutes that are members of the EJT consortium: Muséum national d'Histoire naturelle, Paris, France; Botanic Garden Meise, Belgium; Royal Museum for Central Africa, Tervuren, Belgium; Natural History Museum, London, United Kingdom; Royal Belgian Institute of Natural Sciences, Brussels, Belgium; Natural History Museum of Denmark, Copenhagen, Denmark. 